FILOLOGIJA 71, Zagreb 2018.

UDK 81'272:94(497.5)"1945/1991"

DOI https://dx.doi.org/10.21857/m8vqrtze29

Pregledni članak

Rukopis primljen 2. VI. 2017.

Prihvaćen za tisak 22. X. 2018.

Artur R. Bagdasarov

Losinoostrovskaja, 24, RF-107150 Moskva

a_bagdasarov@mail.ru

\title{
O ETNOJEZIČNOJ POLITICI U SOCIJALISTIČKOJ JUGOSLAVIJI
}

U članku se pokušava kronološki sintetizirati etnojezična politika kao sastavni dio jezične politike na hrvatsko-srpskom književnoštokavskom govornom području Jugoslavije u razdoblju od 1940-ih do 1990ih godina. Sa sociolingvističkoga aspekta raščlanjuju se jezičnopolitički i etnojezični suodnosi od "avnojske" ravnopravnosti četiriju jezika: hrvatskoga, srpskoga, slovenskoga i makedonskoga, preko pokušaja novosadskoga izjednačivanja (1954.) i Deklaracije (1967.), jezičnih ustavnih odredaba do potpunoga razilaženja hrvatskoga i srpskoga raspadom i stvaranjem novih država na postjugoslavenskom prostoru. Prikazani su neuspjeli unitaristički ili jugounitaristički pokušaji spajanja hrvatskoga i srpskoga u jedan jedinstveni "srpskohrvatski/hrvatskosrpski" jezik uz pomoć procesa unifikacije i asimilacije njegovih norma. Etnojezična politika promatrana je u složenom kontekstu općih političkih, društvenih, gospodarskih i međuetničkih zbivanja u tadanjoj višejezičnoj državi.

\section{Uvod}

Etnojezičnom politikom smatra se uređivanje jezično-etničkih odnosa, svjestan utjecaj društva u višejezičnoj i/ili jednojezičnoj zajednici na funkcioniranje suodnosa pojedinih jezika. Etnojezična politika sastavni je dio jezične politike i proučava se u makrosociolingvistici, a također i u kontaktnoj lingvistici. Ona se može provoditi na demokratski način, s obzirom na interese razvoja, zakonodavne zaštite i materijalne potpore svih etnojezičnih zajednica, a može se ostvarivati i na nedemokratski način uz pomoć interesa političke elite ili prevladavajućega, većinskoga naroda (dominantnoga etnosa). Ovisno o rješavanju državnopolitičkih i etno- 
lingvokulturnih zagana, ${ }^{1}$ etnojezična politika može imati pravedan ili pak diskriminacijski značaj. Jedna od diskriminacijskih značajki etnojezične politike u višeetničkoj (polietničkoj) državi je etnojezični unitarizam. Unitarizam je (od lat. unitas - jedinstvo) načelo državnoga ustroja koji počiva na unitarnim osnovama, a također i u težnji centralizacije u području politike, gospodarstva i kulture. Unitarizam je u sociolingvistici vrsta jezične politike koja je usmjerena na ostvarivanje načela »jedna država - jedan etnos - jedinstveni etnojezik «. Državnopolitičko i etnolingvokulturno trojedinstvo ima svoje korijene u Europi 19. st., u svegermanskom (pangermanskom), a kasnije i sveslavenskom (panslavenskom) pokretu. Sveslavenski pokret u Hrvatskoj se, primjerice, izrazio u obliku ilirskoga pokreta, pretvoren je u Strossmayerovo jugoslavenstvo i potom $\mathrm{u}$ posebno integralno jugoslavenstvo prve Jugoslavije, a zatim u pokušaje ostvarivanja jugoslavenstva $u$ etnojezičnoj politici druge Jugoslavije na čelu s većinskim etnosom. Unitarizam zanemaruje etnolingvokulturne razlike i rješavanje nacionalnih problema vidi u sveopćem uzajamnom izjednačivanju (asimilaciji) - $\mathrm{u}$ brisanju etničkih, kulturnih, psiholoških, tradicijskih, državnoorganizacijskih, jezičnih i drugih razlika među narodima (Mečkovskaja 2001:209). Uzgred budi rečeno da unitarni ustroj države ne zahtijeva nužno jaku upravnu (administrativnu) centralizaciju. Primjerice, SFRJ i SSSR su se formalno smatrale federativnim državama, a u stvari je njima bio svojstven unitarizam, centralizacija i reglementacija. U bivšim socijalističkim ili komunistički usmjerenim zemljama unitarizam je bio još ideološki potkrijepljen marksističkom ili marksističko-lenjinističkom naukom, idejama budućega spajanja različitih etnolingvokultura. U glavnim crtama, za jugoslavensku jezičnu politiku svojstven je centralizam, purizam i unutarnji ekspanzionizam. Centralizam se izražavao u težnji da se formira u sklopu federativne države jedan "srpskohrvatski" jezik. Purizam se izražavao u težnji da se stvori i unificira jedan idealno pravilan oblik književnoštokavskoga govora kao osnova za književni (standardni) jezik mimo ponajprije čakavskoga i kajkavskoga narječja i drugih osebujnosti hrvatskoga jezika i da ga se nametne različitim etnolingvokulturnim zajednicama u Jugoslaviji. Ekspanzionizam se izražavao u težnji da se normira, a na kraju ozakoni (kodificira) jedan zajednički "srpskohrvatski" jezik (lingua communis) i da mu se prida sveopća narav, šireći ga u obliku

1 Napomena Uredništva: Autor u svojem tekstu sustavno rabi riječ zagana u značenju riječi problem. Riječ zagana zabilježena je u nekim hrvatskim povijesnim rječnicima. Autor je u suautorstvu s Milanom Nosićem o njoj i o pravu da se njome koristi napisao članak koji je objavljen 2015. godine u časopisu Jezik pod naslovom Materinski jezik - brana jezičnoj globalizaciji (62., str. 141-145). 
"državnoga jezika" ponajprije na područje jezika Hrvata, Bošnjaka, Crnogoraca i Srba, a također djelomice Makedonaca i Slovenaca.

Etnojezičnu politiku u odnosu na jezični jugounitarizam možemo uvjetno podijeliti na dva za hrvatski jezik slična razdoblja, prve Jugoslavije (KSHS 1918. - 1929., KJ 1929. - 1941.) i druge Jugoslavije (DFJ od 1945., FNRJ od 1946. i SFRJ od 1963.) do njezina raspada (1991./92.). U samovladarskom društvu centralizirana jezična politika prve, a zatim i druge Jugoslavije bila je usmjerena na pojačanje državne vlasti u svim područjima društvenoga života, na oslabljenje, a u budućoj perspektivi i na izjednačivanje etnojezičnih razlika pod krinkom društvenopolitičke, ideološke i gospodarske integracije i konsolidacije višeetničkih naroda. Onodobnoj jezičnoj politici svojstvena je težnja prema centralizaciji i monocentrizmu, pružanje povlastica jednoj ("državnoj”) etnojezičnoj zajednici.

U razdoblju Kraljevine Srba, Hrvata i Slovenaca hrvatski je jezik bio zahvaćen valom pravopisne unifikacije slijedeći srpska pravopisna pravila uz dominaciju srpskoga jezika u svim područjima društvenoga života. Mijenja se i naziv hrvatskoga jezika jer je kraljevina višečlanoga "srpskohrvatsko-slovenačkoga naroda" morala imati i jedan službeni naziv jezika - "srpsko-hrvatsko-slovenački" (Ustav KSHS 1921., čl. 3.), uz dominaciju naziva "hrvatski ili srpski" i "hrvatskosrpski / srpskohrvatski" u praksi. U prvoj Jugoslaviji hrvatski se jezik u određenom razdoblju razvijao u ozračju šestosiječanske diktature kada je kralj Aleksandar I. Karađorđević raspustio Narodnu skupštinu, zabranio rad svih političkih stranaka i sindikata, uveo cenzuru te proglasio ideologiju "integralnoga jugoslavenstva", a državu preimenovao 3. listopada 1929. god. u Kraljevinu Jugoslaviju. Jugoslavenska parola te ideologije bila je: »Stvorili smo Jugoslaviju, stvorimo Jugoslavene«. Ako nasljedujemo tu parolu, onda dobijemo rečenicu: »Stvorili smo Jugoslavena, stvorimo jugoslavenski jezik«, tj. u svojoj biti jedan i jedinstveni "srpskohrvatski jezik". Jezični jugounitarizam iskazuje se u pokušaju nametanja ćirilice i potiskivanja latinice, u pokušaju nametanja ekavštine, unificiranja pravopisa i nazivlja (Samardžija 2012). Na djelu je bila jezična, funkcionalno-strukturna najezda (ekspanzija): težnja širenju vladajućega srpskoga etnojezika na tuđu, hrvatsku jezičnu zajednicu. U tom se razdoblju nije radilo samo o spajanju naziva jezika i uklanjanju razlika između hrvatske i srpske pravopisne norme i nazivlja nego i o jačanju tzv. narodnoga jedinstva triju/dvaju "plemena" koje je preraslo nakon Drugoga svjetskoga rata u drugoj Jugoslaviji $u$ »bratstvo i jedinstvo svih jugoslavenskih naroda«. Zbog "narodnoga jedinstva", a zatim "bratstva i jedinstva", dogovoreno je da Hrvati, Srbi, Crnogorci i bosansko-hercegovački Muslimani, a nekoć i Slovenci, imaju jedan i jedinstven jezik, 
čije će političko ime sadržavati dva spojena naziva između kojih je znak jednakosti - "srpskohrvatski/hrvatskosrpski".

Jezična politika SFRJ-a, ili razgovorno - druge Jugoslavije, može se uvjetno podijeliti na dvije suprotne faze razvitka ponajprije u odnosu na hrvatski jezik: 1 . relativno demokratska politika potpore i razvoja etnojezikâ u višeetničkoj zajednici na osnovi jednakosti svih naroda i jezika i 2. unitaristička politika prema narodima i jezicima koja se provodila u korist ponajprije jednoga dominantnoga etnosa i njegova jezika. Prva se faza mirnoga razvoja i ostvarivanja etnojezične politike odnosi na razdoblje od 1944. do 1953. god., od AVNOJ-a do Ankete o pitanjima srpskohrvatskog književnog jezika i pravopisa i tzv. Novosadskoga dogovora. Druga faza burnoga razvoja i provedbe unitarističke etnojezične politike i otpora jugounitarizmu odnosi se na razdoblje od 1954. do 1992. god., od Novosadskoga dogovora preko Deklaracije o nazivu i položaju hrvatskoga književnoga jezika, jezičnih ustavnih odredaba u Ustavu SR Hrvatske 1974. god., tzv. Zagrebačkoga dogovora do raspada SFRJ-a i neovisnoga razvoja hrvatskoga jezika.

\section{Od AVNOJ-a 1943. do Novosadskoga dogovora 1954.}

U tijeku narodnoosloboditeljske borbe i revolucije jugoslavenskih naroda (1941. - 1945.) Komunistička partija Jugoslavije (KPJ) istaknula je parolu »bratstva i jedinstva svih naroda i narodnosti Jugoslavije«. U bosanskom gradu Jajcu 29. i 30. studenoga 1943. god. održano je 2. zasjedanje Antifašističkoga vijeća narodnoga oslobođenja Jugoslavije (AVNOJ) koje je postavilo temelje federativnomu uređenju i stvaranju Nacionalnoga komiteta oslobođenja Jugoslavije (NKOJ) kao prve privremene vlade. Na tom je zasjedanju odlučeno da će se stvoriti nova jugoslavenska država koja će biti izgrađena na načelima ravnopravnosti i samoodređenja svih njezinih naroda. Dvije godine poslije, 29. studenoga 1945., Ustavotvorna skupština u Beogradu proglasila je stvaranje Federativne Narodne Republike Jugoslavije (FNRJ), u čiji je sastav ušlo šest republika i dvije autonomne jedinice: Bosna i Hercegovina, Crna Gora, Hrvatska, Makedonija, Slovenija i Srbija s autonomnom pokrajinom Vojvodinom i autonomnom oblašću Kosovom i Metohijom. Dana 31. siječnja 1946. bio je usvojen prvi Ustav FNRJ-a koji su izaslanici Skupštine pročitali redom na srpskom (M. Pijade), hrvatskom (Z. Brkić), slovenskom (M. Brecelj) i makedonskom (V. Maleski) jeziku. Predsjednišvo Narodnoga sabora Hrvatske 26. veljače 1946. god. objavilo je stvaranje Narodne Republike Hrvatske. Nova država na čelu s KPJ-om utemeljena je, po ugledu na Sovjetski Savez, kao sustav relativno uređenih etnojezičnih hijerarhijskih tvorevina, u sklopovima kojih je službene funk- 
cije trebao vršiti jezik odgovarajućega etnosa. Iznimku je činila Bosna i Hercegovina koja zbog svojega višeetničkoga stanovništva nije bila podijeljena prema nacionalnom načelu.

U Jugoslaviji je bila proglašena pravna ravnopravnost narodâ i jezikâ čija su načela bila određena još na 2. zasjedanju AVNOJ-a. Tako u jednoj odluci AVNOJ-a od 15. siječnja 1944. god., pod brojem 18., piše: „Sve se odluke i obraćanja/proglasi Antifašističkoga vijeća narodnog oslobođenja Jugoslavije i njegova Predsjedništva kao vrhovne zakonodavne vlasti i Nacionalnoga komiteta oslobođenja Jugoslavije kao vrhovne izvršne i administrativne vlasti objavljuju u službenim izdanjima AVNOJ i NKOJ na srpskom, hrvatskom, slovenskom i makedonskom jeziku. Svi su ti jezici ravnopravni na čitavom teritoriju Jugoslavije« (Odluka AVNOJ-a 1989:2). Odluku AVNOJ-a potpisao je njegov tadanji predsjednik Ivan Ribar (1881. 1968.) i tajnik Predsjedništva AVNOJ-a Rodoljub Roćko Čolaković (1900. 1983.). 19. prosinca 1944. god. predsjednik NKOJ-a, maršal Jugoslavije Josip Broz Tito (1892. - 1980.), potpisao je odluku o izdavanju na srpskom, hrvatskom, slovenskom i makedonskom jeziku Službenoga lista Jugoslavije (Babić 1990:13-18). Prvi su, još nesigurni, koraci nove vlasti u oblikovanju etnojezičnih odnosa bili djelomice iznuđeni jer su u prethodnim državnim tvorevinama mnogi narodi već imali vlastito ime svojega jezika. Tako se, primjerice, u Nezavisnoj Državi Hrvatskoj (1941. - 1945.) jezik nazivao hrvatskim, a u Srbiji srpskim. Nova vlast, čini se, nije htjela izgledati manje demokratska od bivših "buržujskih" vlada. Međutim, naziv jezika u republičkim ustavima 1946. - 1947. god. ponešto se mijenja. Tako se u Hrvatskoj sudovanje odvija već na »hrvatskom ili srpskom jeziku, u Srbiji na srpskom, a u autonomnim tvorevinama i na hrvatskom, u Bosni i Hercegovini na srpskom ili hrvatskom jeziku, a u Crnoj Gori na srpskom jeziku« (Karadža 1991:314-315). Pritom se u Ustavu FNRJ-a hrvatsko-srpske etnojezične razlike čuvaju. Usp.: » Nitko ne može biti kažnjen... - Niko ne može...; Obrana domovine najviša je dužnost... - Odbrana otadžbine...; Država vodi brigu o fizičkom odgoju naroda... - Država vodi brigu o fizičkom vaspitanju naroda...; Njezin je zadatak da osigura i brani... - Njen je zadatak da obezbeđuje... (Ustav FNRJ 1957:61, 63, 68; Ustav FNRJ 1955:61, 63, 68).

U poslijeratnom razdoblju u zemlji su se odvijali procesi političke, gospodarske, kulturnoideološke integracije i međuetničke konsolidacije, stvaranje novih oružanih snaga. Važna uloga u procesu stvaranja nadetničkoga društva i superetnosa pridavana je unutardržavnomu jezičnomu jedinstvu. U višeetničkoj, višejezičnoj državi, prema mišljenju tadanjih "jezičnopartijskih" stručnjaka, nužan je zajednički jezik međuetničkoga i međukulturnoga sporazumijevanja, dakle jezik makroposrednik. Taj je makro- 
posrednik trebao vršiti ne samo ulogu sredstva međuetničkoga i međukulturnoga sporazumijevanja nego i ne manje važnu ulogu služenja općedržavnim potrebama (jedinstveno državno upravljanje, svi oblici prometa i vanjskih odnosa, jedinstvena vojska, poštanske veze itd.). Dakako, isticanje općedržavnoga međuetničkoga jezika posrednika u višeetničkoj Jugoslaviji bilo je tretirano i kao oruđe konsolidacije jugoslavenskoga društva, kao jedno od važnih sredstava za odgajanje jugoslavenskoga domoljublja nadetničkoga tipa. Osiguravanje političkoga, socijalnoekonomskoga i međuetničkoga jedinstva, podržavanje i pojačavanje zajedničkoga domoljublja, koje se ponovno pojavilo u godinama narodnoosloboditeljske borbe, dobilo je golemu važnost poglavito poslije raskida odnosa između Jugoslavije i SSSR-a i drugih socijalističkih zemalja koncem 1940-ih i početkom 1950-ih godina kada se pak zemlja našla na rubu oružanih sukoba.

U ulozi makroposrednika ponovno je odabran, kao u razdoblju prve Jugoslavije, sličan jezik, odnosno jezik (npr. Crnogoraca i Srba) kojim se služilo nekoliko naroda: Srbi, Hrvati, Muslimani (Bošnjaci) i Crnogorci. Jezik tih naroda kako u prvoj, tako i u drugoj Jugoslaviji premašivao je svojom rasprostranjenošću i područjem primjene sve ostale jezike i zadovoljavao je, prema tvrdnji tadanje vlasti, potrebe većine stanovništva Jugoslavije. To je, uz ostalo, potvrđivala i činjenica da je dvojezičnost na razini međusobnoga sporazumijevanja bila najraširenija među Slovencima, Makedoncima, Albancima, Mađarima i drugim etničkim skupinama.

Valja također reći da jezici navedenih naroda nisu bili jedinstveni, strogo i konačno normirani, unificirani na područjima na kojima su bili rašireni. Jezici su tih naroda oko dva stoljeća funkcionirali u uvjetima kulturnopovijesne, vjerske, geoetničke, gospodarske, državne (osim prve Jugoslavije) i političke razjedinjenosti naroda na području Hrvatske, Srbije, Crne Gore, Bosne i Hercegovine. U tom još mirnom razdoblju za hrvatski jezik godine 1948. pokrenuto je zagrebačko izdanje Borbe na hrvatskom jeziku, a također je osnovano i izdavačko poduzeće Naprijed koje je objavljivalo marksističku literaturu, također na hrvatskom jeziku. U Zagrebu je 14. veljače 1950. god. osnovano Hrvatsko filološko društvo (Babić 2009:107). Za prvoga predsjednika Društva izabran je Antun Barac (1894. - 1955.), prvim potpredsjednikom postao je Stjepan Ivšić (1884. - 1962.), a tajnikom Zdenko Škreb (1904. - 1985.). Društvo je pokrenulo Jezik (izlazi od 1952.), jezikoslovni časopis za kulturu hrvatskoga književnoga jezika, kojemu je prvi glavni i odgovorni urednik bio Ljudevit Jonke (1907. - 1979.), a započeo je i rad na hrvatskom pravopisu. U izradbi hrvatskoga pravopisa, koji nije došao na svijet, sudjelovali su Josip Hamm, Mate Hraste, Ljudevit Jonke, Slavko Pavešić i Pavle Rogić. »... prve su poslijeratne godine«, piše L. 
Auburger, »bile doduše doba sveopće boljševizacije života u Hrvatskoj, ali ipak su etnički status hrvatskoga naroda i status hrvatskoga jezika kao zasebnoga jezika ostali netaknuti« (Auburger 2009:161).

U drugoj fazi etnojezične izgradnje potrebno je bilo najprvo oslabiti, a zatim izglačati etnojezične razlike. Dolazi do pokušaja slabljenja ili brisanja etnojezičnih razlika, unificiranja i kodificiranja sličnoga književnoga jezika, ponajprije jezika Hrvata i Srba. U ondanje vrijeme centralizirana je jezična politika bila usmjerena na stvaranje zajedničkoga pravopisa i leksika.

\section{Od Novosadskoga dogovora 1954. do Deklaracije o hrvatskom jeziku 1967.}

Sredinom 1950-ih godina pitanjima daljnje unifikacije i kodifikacije zajedničkoga i jedinstvenoga jezika postupno se pridaje kulturnoideološka važnost. U Hrvatskoj je iz tiska 1947. god. izišlo 9. izdanje Boranićeva fonološkoga pravopisa, a godine 1951. i njegovo 10. izdanje. U 10. izdanju iz 1951. god. provedene su pokoje izmjene, a jedna od njih je spojeno pisanje naziva jezika - srpskohrvatski (Hraste 1952:32). Godine 1952. u Srbiji izlazi novo, dopunjeno i prošireno izdanje Belićeva Pravopisa srpskohrvatskog književnog jezika u kojem su uz ekavske likove obrađeni i ijekavski s naglascima. Aktivni proces jezičnoga unitarizma počeo je isprva unifikacijom pravopisâ. U rujnu 1953. god. Letopis Matice srpske u Novom Sadu objavio je anketu Pitanja srpskohrvatskog književnog jezika i pravopisa. Anketa je u svojoj biti predstavljala presliku Skerlićeve ankete iz 1913. god. u kojoj se izjašnjavalo za unifikaciju ijekavskoga i ekavskoga govora (u korist ekavskoga) i latiničnoga i ćiriličnoga pisma (u korist latinice) radi postizanja zajedničkoga i pojednostavnjenoga jezika. U njoj su sudjelovali tadanji poznati jugoslavenski lingvisti, pisci, novinari i društveni djelatnici: A. Belić, I. Frangeš, M. Franičević, J. Hamm, M. Hraste, Lj. Jonke, P. Skok, M. Stevanović, S. Vinaver i dr. Zatim je u Novom Sadu od 8. do 10. prosinca 1954. god. održano savjetovanje na kojem je usvojena rezolucija Novosadskoga književnoga dogovora od deset točaka. U njoj se izjavljuje da Srbi, Hrvati i Crnogorci govore jednim jezikom. Književni jezik, koji se razvija na osnovi jedinstvenoga narodnoga jezika oko dvaju kulturnih središta, Beograda i Zagreba, predstavlja jedinstveni jezik s dvjema izgovornim normama, ekavskom i ijekavskom. Službeni naziv jezika mora imati dvije sastavnice i upozoravati na dva naroda koji tim jezikom govore Srbe i Hrvate - "srpskohrvatski/hrvatskosrpski jezik". Ćirilično i latinično pismo proglašeni su ravnopravnima na cijelom području prostiranja toga 
jezika. Na savjetovanju je bila usvojena odluka da se zajedničkim snagama pripremi i objavi rječnik suvremenoga "srpskohrvatskoga/hrvatskosrpskoga" književnoga jezika; isticana je zadaća izradbe jedinstvenoga nazivlja. Bila je osuđena praksa "prevođenja" tekstova, napisanih u raznim kulturnim središtima, s jedne inačice jezika na drugu. Sudionici savjetovanja odlučili su hitno izraditi jedinstvena pravopisna pravila. Rezoluciju Novosadskoga dogovora potpisalo je 25 književnika i jezikoslovaca (iz Hrvatske 7, iz Srbije 15, iz Bosne i Hercegovine 3), pridružila su im se još 64 djelatnika iz kulture i znanosti, među kojima su bili i poznati pisci Miroslav Krleža (1893. - 1981.) i Ivo Andrić (1892. - 1975.) (Dogovor o jeziku... 1989:2). S hrvatske su strane na novosadskom skupu sudjelovali M. Božić, M. Franičević, J. Hamm, Lj. Jonke, J. Kaštelan i Z. Škreb.

U skladu s Rezolucijom Novosadskoga dogovora stvoreno je povjerenstvo od predstavnika beogradskoga, zagrebačkoga i sarajevskoga sveučilišta, Srpske akademije nauka i Jugoslavenske akademije znanosti i umjetnosti, kojemu je povjereno da izradi nacrt novih pravopisnih pravila. U povjerenstvo za izradbu novih pravopisnih pravila ušli su R. Aleksić, A. Belić, M. Hadžić, J. Hamm, M. Hraste, Lj. Jonke, R. Lalić, S. Pavešić, P. Rogić, M. Stevanović i J. Vuković. Kao rezultat njihove suradnje 1960. god. usporedno je izdan (latinicom) u Zagrebu Pravopis hrvatskosrpskoga književnog jezika i (ćirilicom) u Novom Sadu Pravopis srpskohrvatskog književnog jezi$k a$. Tim su se pravopisnim pravilima uspjela riješiti sporna pravopisna pitanja, premda se nisu uspjela izbjeći sva mimoilaženja među dvjema pravopisnim normama. Novi pravopis predstavljao je svojevrstan pravopisni kompromis, slitinu pravopisnih pravila A. Belića u Srbiji i D. Boranića u Hrvatskoj. Za pojedinu nacionalnu inteligenciju to je doba velikih promjena, nada i iščekivanja, ali iluzornih, kako se uskoro pokazalo.

Godine 1963. usvojen je novi ustav kojim ne samo da je promijenjeno ime države (Federationa Narodna Republika Jugoslavija u Socijalistička Federationa Republika Jugoslavija), nego je i pravno određen novi lingvonim: srpskohrvatski/hrvatskosrpski jezik, kodificiran u zajedničkom pravopisu iz 1960. god. U 131. članku Ustava SFRJ-a zapisano je: »Savezni zakoni i drugi opšti akti saveznih organa objavljuju se u službenom listu federacije $u$ autentičnim tekstovima na jezicima narodâ Jugoslavije: srpskohrvatskom odnosno hrvatskosrpskom, slovenačkom i makedonskom. Organi federacije u službenom opštenju pridržavaju se načela ravnopravnosti jezikâ narodâ Jugoslavije« (Ustav 1964:78). U republičkim ustavima Srbije, Crne Gore, Bosne i Hercegovine službeno je bila u porabi inačica "srpskohrvatski jezik", a u Hrvatskoj "hrvatskosrpski".

U višeetničkim socijalističkim zemljama odsutnost zajedničkoga, jed- 
noga jezika predstavljala je i ozbiljnu izvanjezikoslovnu smetnju za nadzor u svim područjima društvenoga života, vodila k razjedinjenosti stanovništva, što nije doprinosilo jačanju i učvršćivanju centralizirane državne vlasti u Jugoslaviji. Zbog toga se pojavljuje potreba druge faze etnojezične politike koja ide usporedno s centralizacijom ideološke, političke i gospodarske vlasti.

Na prvi pogled službeno prihvaćanje Novosadskoga dogovora nije značilo ukidanje razlika ili svjestan utjecaj na miran razvoj jezika Hrvata, Srba, Crnogoraca i Muslimana, nije davalo prednost ovoj ili onoj etnolingvokulturnoj zajednici. Istodobno s tim 1950-ih i 1960-ih godina srpskohrvatski (srpski) književni jezik širi i učvršćuje područje svojega utjecaja. Tako, na primjer, nakon Novosadskoga dogovora 1950-ih i 1960-ih godina Statistički kalendar izlazi na nekoliko jugoslavenskih službenih jezika, ali ne i na " $h r$ vatskosrpskom" (hrvatskom) jeziku (do 1971.); na zagrebačkom radiju vijesti u 22.00 sata do 1958. god. emitiraju se u ekavskoj normi izgovora; 1950ih godina administracija nastoji ograničiti porabu hrvatskih naziva mjeseci (siječanj, veljača, ožujak, travanj i dr.) i sl. (Jonke 1971:31-49). Sredinom 1950-ih i početkom 1960-ih godina M. Lalević izdaje u Beogradu priručnike Naš pravopis i Srpskohrvatski u mom džepu gdje srpske riječi kao na primjer: Jugosloven, Vavilon, hemija, kafa i druge određuje kao "prihvatljivije" u suodnosu prema odgovarajućim riječima u hrvatskom: Jugoslaven, Babilon, kemija, kava i druge (Lalević 1963). Iste godine (1963.) izlazi Rečnik ruskog $i$ srpskohrvatskog jezika M. Moskovljevića u kojem hrvatske riječi kazalište, kolodvor, kruh, otok, rajčica, zrak i druge autor označuje kao regionalne, tj. dijalektalne ili provincijalne (Moskovljević 1963). Dio tih "nepreporučljivih" ili "nestandardnih" riječi nije mogao ući u sustav "zajedničkoga" standardnoga (štokavskoga) jezika. Navedeni tekstovi izazvali su prosvjede i kritiku ponajprije od strane hrvatskih jezikoslovaca (Jonke 1971:305, 365; Vince 1959/60:60; Finka 1966/67:69; Ujčić 1966/67:150). Valja reći da je proces uvrštavanja neutralnih hrvatskih riječi među stilski obilježene postojao i u prijašnjem razdoblju zajedničkoga života Hrvata i Srba u Kraljevini Jugoslaviji (1929.). Kako je uočio I. Pranjković, 1930-ih godina mnoge su hrvatske riječi u beogradskom jezičnom časopisu Naš jezik (izlazi od 1932.) srpski jezikoslovci ubrajali $u$ arhaizme, barbarizme, provincijalizme, dijalektizme ili u umjetne tvorevine. Primjerice, hrvatske riječi ubojstvo, tko, taliti proglašavaju se arhaizmima; naputak, spodoba, kralježnica provincijalizmima; tlak, dojam, tajnik barbarizmima, a četvero, uporaba, rabiti, osebujnost određuju se kao dijalektizmi (Pranjković 1998:147-155). U poslijeratnom razdoblju, bilježi S. Vukomanović, srpski je unitarizam težio »umjetnom spajanju i brisanju kulturnih i jezičnih posebnosti. Jugoslavenstvo se 
često poimalo u tom razdoblju kao (nad)nacija« (Vukomanović 1987:94).

U tim su uvjetima težnju da se jezik najbrojnijega etnosa iskoristi za unutardržavnu integraciju pojedini djelatnici hrvatske kulture i znanosti, te društvene ustanove u Hrvatskoj doživljavali kao očitovanje unitarizma od strane vladajućega, dominantnoga etnosa, etnojezične diskriminacije, posezanje za njihovim ustavnim pravima, izazivajući kao odgovor na to pojačane težnje za republičkim i etnojezičnim razgraničenjem i odvajanjem. Pokušaji unificiranja književnoga jezika navedenih naroda, u socijalnopolitičkim i gospodarskim uvjetima koji su u to doba bili nastali, doveli su do suprotnih učinaka. Pojačali su hrvatski lingvoregionalizam koji je pratio regionalizam na socijalnogospodarskoj podlozi. Bit lingvoregionalizma svodi se na učvršćivanje i obranu materinskoga jezika stanovništva republike, na težnju da se dokaže njegova samosvojnost i osebujnost, visoka priopćajna vrijednost, njegova slavna prošlost (Černyšev 1978:145146). Unitaristička doktrina marksističkoga "jugoslavizma" u praksi je prerasla u svoju suprotnost, u ideje gospodarskoga, političkoga (republičkoga), etnojezičnoga, a u perspektivi i državnoga razgraničavanja i diobe.

U socijalnopolitičkim uvjetima koji su nastali jezik je, kao društvena pojava, sve više i više dobivao politički značaj. Jedan od razloga zaoštravanja jezičnih pitanja bio je ponajprije u neriješenim međuetničkim odnosima. Međuetnička su se i međurepublička proturječja poglavito zaoštrila koncem 1960-ih i početkom 1970-ih godina. Preko Hrvatske, Srbije i Slovenije prešao je val studentskih istupanja i štrajkova sa zahtjevima da se ubrza proces reformi, da se republikama dâ veća gospodarska i politička samostalnost. U cjelini su pak »međunacionalna proturječja obično određena socijalnoekonomskim čimbenicima« (Bromlej 1983:334). Međurepublička su se i međuetnička proturječja zaoštravala kao posljedica opće decentralizacije gospodarskoga i političkoga sustava jedinstvene federativne države. Radi rješavanja sve većega broja problemâ i proturječjâ, od 1965. god. počela se provoditi socijalnogospodarska reforma. U njezinu su se tijeku primjetno zaoštrila međurepublička i međuetnička proturječja. U tim uvjetima došlo je do pokušaja da se pitanje međuetničkih odnosa riješi reformom političkoga sustava. U razdoblju od 1967. do 1971. god. unošene su izmjene u Ustav SFRJ-a koje su znatno proširile prava republikâ u vidu veće gospodarske i političke samostalnosti. Ali, u zemlji je bilo sve više kriznih pojava koje su produbljivale decentralizaciju u mjeri u kojoj se prelazilo iz centralizirane federativne države $u$ decentralizirani konfederativni ustroj (Kameneckij 1985:16-25).

Težnje za osamostaljenjem jugoslavenskoga narodnoga gospodarstva u 
granicama republikâ i pokrajinâ, za prijelaz od federativnoga na konfederativni ustroj jačale su nacionalno i teritorijalno-administrativno osamostaljivanje republikâ, izazivajući međurepublička i međuetnička proturječja, a ova su opet davala oštrinu jezičnomu pitanju, pogodovala su lingvoregionalizmu i divergentnomu razvoju ponajprije hrvatskoga i srpskoga jezika. Sve se to, dakako, odrazilo na sudbinu odluka Novosadskoga dogovora. Svijest dijela društva o etnolingvokulturnom zajedništvu, kao i o korisnosti i svrsishodnosti porabe jednoga kodificiranoga jezika makroposrednika u višeetničkom društvu, s jedne strane, i strah za sudbinu vlastite etnolingvokulture s druge, nisu pogodovali daljnjemu jezičnomu udruživanju na osnovi kompromisâ. Nisu dali uspjeha ni pokušaji provedbe zajedničke jezične politike, standardizacije i kodifikacije, uz dezintegraciju socijalnogospodarskih i političkih procesa (Bagdasarov 2004:37-38). Jezičnopolitička dogovorna lingvistika iz razdoblja tzv. Novosadskoga dogovora 1954. god. poništena je Deklaracijom o nazivu i položaju hrvatskoga književnoga jezika iz 1967. godine.

\section{Od Deklaracije do jezične odredbe o hrvatskom jeziku u Ustavu SRH 1974.}

Ponovno nametanje srpskohrvatskoga (srpskoga) jezika kao državnoga jezika makroposrednika, opasnost etnojezičnoga izjednačivanja (asimilacije), nepostojanje vlastitoga etnolingvonima i ograničavanje prava na porabu vlastitoga jezika izazvalo je val prosvjeda pojedinih hrvatskih, slovenskih i makedonskih intelektualaca, znanstvenih ustanova i kulturnih društava. Jezičnopolitički otpori i nesuglasice s provedbom centralizirane, unitarističke etnojezične politike počeli su u ozračju nakon Brijunskoga plenuma CK SKJ (1. srpnja 1966.) i smjene Aleksandra Rankovića (1909. - 1983.), dopredsjednika SFRJ-a. Na osnovi ustavnih odredaba o ravnopravnosti jezikâ slovenske kulturne i znanstvene ustanove poslale su 3. veljače 1967. god. otvoreno pismo Radioteleviziji Ljubljana sa zahtjevom emitiranja televizijskoga programa samo na slovenskom jeziku jer je više od polovice programa išlo na srpskohrvatskom (srpskom) jeziku (Batović 2010:581). Godine 1965. i 1966. neke su znanstvene ustanove i društva Hrvatske (Društvo književnika Hrvatske, Zagrebački lingvistički krug Hrvatskoga filološkoga društva, znanstveni kolektiv Instituta za jezik JAZU) istupili u časopisu Jezik protiv gaženja ustavnih prava hrvatskoga naroda, protiv neopravdanoga miješanja djelatnika medija $u$ tekstove izvornika te pozvali na samostalan razvoj i naziv svojega jezika (Zaključci plenuma Društva književnika Hrvatske 1966:129-133). U Zagrebu 9. ožujka 
1967. god. Uprava Matice hrvatske odabire povjerenstvo od 7 članova kojemu je povjereno da izradi tekst deklaracije o pravu hrvatskoga jezika na vlastito ime i ravnopravnu porabu među drugim jugoslavenskim jezicima. U povjerenstvo Upravnoga odbora $\mathrm{MH}$-a ušli su poznati hrvatski jezikoslovci i književnici, javni i kulturni djelatnici: M. Brandt, D. Brozović, R. Katičić, T. Ladan, S. Mihalić, S. Pavešić, V. Pavletić. Kao neposredan povod za pisanje deklaracije poslužilo je obraćanje Savezne skupštine građanima zemlje da svestrano razmotre Ustav SFRJ-a iz 1963. god. i predlože izmjene. Nakon duge rasprave tekst Deklaracije o naziou i položaju hrvatskog knjižeonog jezika bio je prihvaćen, prema jednim izvorima, većinom glasova (prema sjećanjima L. Županovića, dva su glasa bila protiv), a jednoglasno prema drugima. Deklaracija je objavljena 17. ožujka 1967. god. u zagrebačkom tjedniku Telegram, uz napomenu da se upućuje Saboru SR Hrvatske i Saveznoj skupštini SFRJ-a kao prijedlog u sklopu priprava za promjenu Ustava. Tekst Deklaracije potpisalo je 18 znanstvenih, znanstveno-nastavnih ustanova i društava (Matica hrvatska, Društvo književnika Hrvatske, Hrvatsko filološko društvo, Institut za jezik JAZU, katedre za suvremeni hrvatskosrpski jezik Filozofskoga fakulteta u Zadru i Filozofskoga fakulteta u Zagrebu, Društvo književnih prevodilaca Hrvatske i dr.). U njoj se tvrdilo da se ne ostvaruje odredba Novosadskoga dogovora iz 1954. god. o pravu svakoga naroda na samostalan i ravnopravan razvoj jezika te da se provodi koncepcija jedinstvenoga "državnoga jezika", pri čem u ulozi "državnoga jezika" nastupa srpski književni jezik. Taj se "državni jezik" preko administrativno-upravnoga aparata, medija, porabe jezika u Jugoslavenskoj narodnoj armiji, saveznom zakonodavstvu, diplomaciji i političkim organizacijama nameće kao jedinstveni jezik Hrvata i Srba. Time se, prema mišljenju autorâ Deklaracije, hrvatski književni jezik istiskivao i stavljao u neravnopravan položaj "lokalnoga narječja”, tj. u položaj područnoga dijalekta srpskoga književnoga jezika. Hrvatska jezična zajednica tražila je jasniju formulaciju etnolingvonima u članku Ustava, kao i davanje pravnih jamstava za očuvanje ravnopravnoga razvoja etnolingvokulturne raznolikosti jugoslavenskih naroda i narodnih manjina. U svezi s tim autori Deklaracije predlagali su izmjenu formulacije članka Ustava SFRJ u kojem se govori o "srpskohrvatskom/hrvatskosrpskom jeziku". Predlagana je izmjena sljedećega sadržaja: "Savezni se zakoni i drugi opći akti saveznih organa objavljuju u autentičnom tekstu na četiri književna jezika naroda Jugoslavije: srpskom, hrvatskom, slovenskom, makedonskom. U službenim se odnosima organi federacije moraju pridržavati principa ravnopravnosti svih jezika naroda Jugoslavije«. Autori Deklaracije ističu da formulacija temeljnoga zakona zemlje o "srpskohrvatskom/hr- 
vatskosrpskom jeziku" zbog svoje nepreciznosti u praksi omogućuje slobodno tumačenje ovih naziva kao istoznačnica, a ne kao osnove za ravnopravnost hrvatskoga i srpskoga književnoga jezika. Znanstvene i društvene organizacije koje su potpisale Deklaraciju zahtijevale su da se osigura dosljedna poraba hrvatskoga književnoga jezika u svim područjima hrvatskoga javnoga i društvenoga života (Deklaracija o nazivu i položaju hrvatskog književnog jezika 1997). Deklaracija je nastala kao zdvojan postupak u borbi za etnojezični opstanak i samosvojnost. 19. ožujka 1967. god. održan je plenum Saveza pisaca Srbije na kojem je, kao odgovor na hrvatsku Deklaraciju, usvojena odluka o objavljivanju srpske deklaracije. U Borbi je 3. travnja 1967. god. objavljena deklaracija pod nazivom Predlog za razmišljanje (Predlog za razmišljanje 1967:5). U tom dokumentu, pod kojim su bila 42 potpisa, pozivalo se na poništavanje odluka tzv. Bečkoga književnoga dogovora iz 1850. i Novosadskoga dogovora iz 1954. godine. Autori Predloga za razmišljanje deklarirali su pravo na samostalan i ravnopravan razvoj hrvatskoga i srpskoga jezika.

Oba jezičnopolitička manifesta zapravo su samo zaoštrila međuetnički jezični sukob priznavši pravo na postojanje samostalnih književnih jezika. U mnogobrojnim tekstovima koji su se pojavili u tadanjim medijima Deklaracija i Predlog bili su ocijenjeni kao pokušaj rušenja "bratstva i jedinstva jugoslavenskih naroda". Stavovi izneseni u tim dokumentima dočekani su s osudom od strane vladajuće komunističke partije. Mnogi kulturni djelatnici, članovi SKJ-a, koji su ih potpisali ili su u njima aktivno sudjelovali, bili su isključeni iz Partije ili su dobili stroge partijske ukore. Među njima su bili M. Brandt, D. Brozović, D. Car, I. Frangeš, Lj. Jonke, Z. Komarica, V. Kuzmanović, S. Mihalić, J. Ravlić, a za njima izlazi iz partije i M. Krleža, predavši pismenu izjavu u CK SKH (Pavičić 1991:23). Centralni komiteti Saveza komunista Srbije, Hrvatske te Bosne i Hercegovine 1967. i 1968. god. objavili su posebne dokumente u kojima su pozivali na uklanjanje nedostataka i propusta $u$ jezičnoj teoriji i praksi. U njima se nisu dovodile u pitanje odluke Novosadskoga dogovora. Riječ je bila prije svega o njihovu dosljednijem provođenju u životu, o tome da »otvorena jezična pitanja treba rješavati mirno i trijezno, s punom znanstvenom i političkom odgovornošću « (Izvršni komitet CK SKH i CK SKS 1968:65-67). Međutim, ti su pozivi imali prije deklarativan i djelomično smirujući karakter, nego što su predstavljali zakonodavno, praktično ostvarivanje stvarne ravnopravnosti. Državna vlast, na čelu s komunističkom partijom, često je više gušila ili na neko vrijeme gasila različite centrifugalne tendencije negoli ih razrješavala. 
Veliku pozornost i oštru reakciju izazvalo je u Hrvatskoj objavljivanje prvih dvaju svezaka Rječnika hrvatskosrpskoga/srpskohrvatskoga književnog jezika. Još su prije Novosadskoga dogovora Matica hrvatska i Matica srpska započele izradbu općega jednojezičnoga rječnika. Godine 1967. objavljena su dva sveska (do slova K, tzv. "Adok"), tiskana latinicom i ćirilicom u Zagrebu i Novom Sadu. U Zagrebu je taj rječnik podvrgnut oštroj kritici. Rječnik je, uz ostalo, bio kritiziran zbog toga što u njem nije bilo mnogih hrvatskih riječi, što su za ilustracije u njem porabljena uglavnom djela srpskih pisaca (Brozović 1969:19-88; Selak 1992:79-84). Matica hrvatska je 1969. god. odustala od objavljivanja nastavnih svezaka, obrazlažući odustajanje potrebom da se rječnik doradi te nedostatkom financijskih sredstava. Matica srpska je sljedeća četiri sveska tiskala samo ćirilicom. Odustajanje od zajedničkoga izdavanja rječnika poslužilo je kao povod za raskidanje Novosadskoga dogovora. Godine 1971. Matica hrvatska, Institut za jezik Jugoslavenske akademije znanosti i umjetnosti, Društvo književnika Hrvatske i druge znanstvene ustanove te hrvatska kulturna društva jednostrano su raskinuli Novosadski dogovor. U lipnju 1971. u časopisu Kritika, br. 18., novinarka Glasa Koncila Smiljana Rendić (1926. - 1994.) u članku Izlazak iz genitiva ili drugi hrvatski preporod piše: »Torturu rastapanja hrvatskoga identiteta, torturu Novosadskog dogovora u kojemu je prisutnost hrvatskih jezikoslovaca bila samo čin očajne odgovornosti pred vlastitom nacijom, strahovito gorki pokušaj da se barem spriječi posvemašnje i bešćutno odlučivanje o nama bez nas, torturu apsurdnoga Novosadskog pravopisa koji je nevjerojatnim akrobacijama na silu od dva jezična osjećaja i dva književna jezika pravio jedan, torturu koja nam je i samo ime materinskog jezika, jezika hrvatskoga, jezika koji za Hrvata nikakvo drugo ime ne može imati, mučila nenaravnom imenskom simbiozom kakve nema nigdje na svijetu, pa ni u imenima jezika mnogo sličnijih nego što su hrvatski književni i srpski književni jezik « (Rendić 2012). Uzgred budi rečeno, taj svezak časopisa Kritika bio je zabranjen, a Smiljana Rendić poslije je osuđena na godinu dana zatvora i još na godinu dana zabrane javnoga djelovanja.

Valja reći da metoda reguliranja međujezičnih odnosa sklapanjem kompromisnih društvenih dogovora i sporazuma, uz odobrenje i pod paskom republičkih i centralnih partijskih organa, nije dovela do ostvarenja planiranoga cilja. Nijedna od točaka Novosadskoga dogovora nije bila u potpunosti ostvarena. Primjerice, nova pravopisna pravila (1960.) nisu uklonila postojeće razlike između hrvatske i srpske norme. Svaka se jezična zajednica pridržavala u pravopisu tradicije koja joj je bila bliža i uobičajena. U zajedničkim pravopisnim pravilima dopušta se slobodna poraba fonetsko- 
-fonemskih međujezičnih inačica, kao što su Cipar i Kipar, kaos i haos, kemija i hemija, ocean i okean, opći i opšti itd., ali u hrvatskoj jezičnoj zajednici, u pravilu, rabe se samo Cipar, kaos, kemija, ocean, opći, a u srpskoj samo Kipar, haos, hemija, okean, opšti. Službeni naziv jezika, koji je prihvaćen u zajedničkom pravopisu i potvrđen $u$ Ustavu, nije se $u$ istoj mjeri jednako rabio u četirima republikama čiji je službeni jezik bio "srpskohrvatski/hrvatskosrpski". Hrvatski, srpski i sarajevski jezikoslovci nisu pristupili izradbi jedinstvenoga nazivlja zbog nastalih jezičnih nesuglasica. Nije bila prestala niti praksa prevođenja djelâ s jednoga jezika na drugi.

Procesi konvergencije i unificiranja jezika, te istodobno njegove divergencije i diferenciranja, nisu jugoslavensku jezičnu zajednicu i njezinu nacionalnu (hrvatsku, srpsku) inteligenciju doveli do stanja jezične snošljivosti i međusobne lojalnosti. U Hrvatskoj je počelo daljnje kodificiranje hrvatskoga jezika neovisno o srpskom.

Godine 1971. u Hrvatskoj je trebao biti objavljen Hrvatski pravopis S. Babića, B. Finke i M. Moguša. Te godine Republički sekretarijat (ministarstvo) za prosvjetu i kulturu Hrvatske zabranio je njegovo izdavanje i porabu u školama jer je pravopis, poglavito rječnik, bio usmjeren, po mišljenju Republičkoga sekretarijata, samo »na zapadnu varijantu hrvatskosrpskoga jezika«. Mnoge su riječi u njem bile protumačene kao iskazivanje »jezičnoga nacionalizma ili separatizma«. Međutim, 1972. god. izdala ga je emigrantska izdavačka kuća Nova Hrvatska u Londonu (kolokvijalno se zato naziva "londoncem"). Kad je dospio u Jugoslaviju, određeni ga je dio hrvatskih urednika i novinara počeo rabiti kao priručnik u pripremi različitih tekstova za tisak. U Zagrebu su 1971. god. Slavko Pavešić (1912. 1975.) i dr. objavili Jezični savjetnik s gramatikom koji je imao savjetodavnu narav i bio je namijenjen, prema riječima autora, ponajprije hrvatskim čitateljima. Osim oznaka stila, u njem su i posebne primjedbe koje govore o teritorijalnoj rasprostranjenosti riječi. Tako se, primjerice, čorba, kako kažu sastavljači savjetnika, obično rabi u istočnim i južnim krajevima, a juha $\mathrm{u}$ zapadnim; hor u istočnim, a kor u zapadnim; lala obično na istoku, a tulipan na zapadu (Pavešić 1971:55, 91, 134).

Godine 1973. u Zagrebu je trebalo izići 6. izdanje Gramatike hrvatskosrpskoga jezika za srednje općeobrazovne škole S. Babića i S. Težaka s novim predgovorom i izmijenjenim nazivom Pregled gramatike hrvatskoga književnog jezika. Izdavačka kuća Školska knjiga, bojeći se još jedne zabrane od strane Republičkoga sekretarijata za prosvjetu i kulturu Hrvatske, predložila je autorima da izmijene tekst predgovora, $\mathrm{u}$ kojem se $\mathrm{u}$ »neprihvatljivoj za izdavača formi izlagala autohtona povijest razvoja hrvatskoga književnog 
jezika«. Pregled gramatike hrvatskoga književnog jezika izišao je 1974. god. u Londonu u izdanju Nove Hrvatske (Selak 1992:85-86).

Neuspjesi zajedničkoga jezičnoga planiranja umnogome su povezani s neadekvatnim prihvaćanjem opće tendencije društveno-gospodarskoga, političkoga i jezičnoga razvoja, kao i povijesti međuetničkih odnosa dvaju naroda. Pokušaji ubrzavanja međujezičnoga ujedinjenja nisu odgovarali procesima unutardržavnoga razjedinjenja (dezintegracije).

\section{Od Ustava SRH 1974. do Zagrebačkoga dogovora 1986.}

Godine 1974. u SFRJ-u je bio prihvaćen novi ustav koji je razlikovao dva pojma: narod - 'autohtoni etnos' i narodnost - 'etnos, glavni dio kojega, u pravilu, živi izvan Jugoslavije'. Narodi su: Crnogorci, Hrvati, Makedonci, Muslimani (od 1967.), Slovenci, Srbi, a narodnosti: Albanci, Bugari, Česi, Mađari, Rusini, Slovaci, Talijani, Turci, Ukrajinci i dr. U zemlji je nabrojeno petnaestak jezika. Ustav iz 1974. god. ostavljao je rješavanje jezičnoga pitanja na volju republikama i pokrajinama. Federalni zakoni i pravni akti bili su objavljivani na jezicima subjekata Federacije. Tako, primjerice, u skladu s člankom 269., "Savezni zakoni i drugi propisi i opšti akti donose se i objavljuju u službenom glasilu Socijalističke Federativne Republike Jugoslavije u autentičnim tekstovima na jezicima narodâ Jugoslavije utvrđenim republičkim ustavima. Savezni zakoni i drugi propisi i opšti akti objavljuju se u službenom glasilu Socijalističke Federativne Republike Jugoslavije kao autentični tekstovi i na jezicima albanske i mađarske narodnosti«(Ustav SFRJ 1974:58). Prema članku 138., stavak 1. Ustava Socijalističke Republike Hrvatske od 22. veljače 1974. god. »u Socijalističkoj Republici Hrvatskoj u javnoj je upotrebi hrvatski književni jezik - standardni oblik narodnog jezika Hrvata i Srba u Hrvatskoj, koji se naziva hrvatski ili srpski«(Ustav SFRJ 1974:315). U Ustavu Srbije službeno se rabi srpskohrvatski jezik (lingvonim se ne mijenja), u Bosni i Hercegovini srpskohrvatski/hrvatskosrpski u ijekavskoj izgovornoj normi, u Crnoj Gori srpskohrvatski s ijekavskim izgovorom, u Sloveniji slovenski, u Makedoniji makedonski, na Kosovu albanski, srpskohrvatski i turski, u Vojvodini srpskohrvatski/ /hrvatskosrpski, mađarski, slovački, rumunjski i rusinski. Mediji rabe deset jezika. Nastava se i odgajanje u dječjim vrtićima, školama i na fakultetima izvodi, u većem ili manjem opsegu, na jezicima subjekata Federacije, ali i na talijanskom (Hrvatska i Slovenija), turskom (grad Priština), slovačkom, rumunjskom, rusinskom (Vojvodina). Bugarski, češki i ukrajinski jezici (u nekim područjima Bosne i Hercegovine, Srbije, Hrvatske) rabe se u dječjim vrtićima i u nižim razredima osnovnih škola, romski u početnim ra- 
zredima osnovnih škola (u nekim općinama na Kosovu) (Škiljan 1988:84; Gak 1989:122-123).

Jezična ravnopravnost u zemlji nailazila je na tehničke poteškoće: trebalo je praktično sve - od federalnih ustavnih zakona, pravnih akata, odluka i propisa federalnih i republičkih organa vlasti do zemljopisnih naziva, prometnih znakova i etiketa na proizvodima - napisati na nekoliko jezika subjekata Federacije, što je pak stvaralo znatne troškove. Na primjer, proizvođači slastičarskih i drugih proizvoda na etiketama su često pisali: Garancija za kvalitet proizvoda (srpski jezik) - Garancija za kvalitetu proizvoda (hrvatski jezik) - Garancia kvalitete izdelka (slovenski jezik) - Garancija za kvalitetot na proizvodot (makedonski jezik).

Bez obzira na opći demokratizam u jezičnoj politici, u zemlji su se i dalje javljale sve veće napetosti $u$ međuetničkim i međujezičnim odnosima. U Sloveniji su, primjerice, ti problemi umnogome bili povezani s etnodemografskim promjenama koje su se tu zbile u poslijeratnim godinama - znatnim priljevom stanovništva iz drugih krajeva Jugoslavije. Te su promjene u Sloveniji u znatnoj mjeri bile uvjetovane (zahvaljujući donekle razvijenijoj infrastrukturi i bolje plaćenu radu) intenzivnom izgradnjom industrijskih poduzeća. Etnolingvokulturne razlike, a dijelom i posebnost socijalnoga statusa doseljenoga stanovništva $u$ odnosu prema mjesnomu stanovništvu, stvarali su podlogu za zaoštravanje etnojezičnih osjećaja. Migranti su često odbijali učiti slovenski jezik - službeni jezik Slovenije, ponajprije zbog sličnosti južnoslavenskih jezika i, drugo, zato što su Slovenci, u pravilu, znali jezik migranata. $S$ druge pak strane, Makedonci su sve češće izražavali bojazan za sudbinu svojega jezika jer je, po njihovu mišljenju, makedonski jezik bio pod snažnim utjecajem "srpskohrvatskoga" (srpskoga) jezika.

Početkom 1980-ih godina u SFRJ-u su se pojačale težnje za decentralizacijom jedinstvene države. Ekonomist K. Mihajlović konstatira:

»Uspostavom samostalnosti republika, njihove suverenosti i odgovornosti za vlastiti razvitak, a također i veće autonomije pokrajina, jedinstveni gospodarski sustav prestao je postojati. Sve republike i pokrajine su donosile svoje petogodišnje planove razvitka, provodile vlastitu poreznu i valutnu politiku... Proturječja interesa republika i pokrajina teško se prevladavaju postizanjem dogovora i sporazuma. Sve to moralo je dovesti do narušavanja jedinstvenoga jugoslavenskoga tržišta. S obzirom na to da Federacija nema više nikakvih ključnih funkcija, osim onih koje joj prepuštaju republike, sadanja se situacija može okarakterizirati kao prijelazno stanje od federacije ka konfederaciji...« (Mihajlović 1986:190-191). 
Prijelaz od centralizirane federativne države $\mathrm{k}$ decentraliziranomu konfederacijskomu ustroju izazvao je porast nacionalne svijesti svih nacija. Procesi unutaretničke konsolidacije počeli su prevladavati nad procesima međuetničke konsolidacije. Unutardržavna dezintegracija udvostručila je međuetnički jezični prijepor koji je počeo zahvaćati i višeetničku vojsku. Tijekom gospodarske krize dugovi Jugoslavije početkom 1980-ih godina popeli su se na oko dvadeset milijardi dolara, a inflacija je skočila na oko $45 \%$ posto. Srpski Memorandum SANU iz 1986. god. u kojem se tvrdi da decentralizacija vodi raspadu Jugoslavije te da su Srbi diskriminirani u Ustavu iz 1974. god. još je više pogoršao opće stanje u zemlji i ubrzao njezinu dezintegraciju.

Nastojanje da se izglade etnojezične razlike Hrvata i Srba vidi se u hrvatskoj i srpskoj leksikografiji. Prijašnja se leksikografija odlikovala odsutnošću registracije ili nedosljednom porabom hrvatskih i srpskih riječi. U rječnicima su se polarizirane hrvatske i srpske leksičke jedinice obrađivale različito: uvrštavale su se ovisno o mjestu izdanja (u Hrvatskoj samo milijun, u Srbiji milion), ili su se navodile u sustavu istoznačnoga ili varijantnoga reda bez upute na njihovu normativnu odrednicu (u Hrvatskoj - vlak, voz, u Srbiji - voz, vlak), ili su bile popraćene oznakom 'v.' (i u ovom slučaju sastavljači su rječnika davali prednost leksičkoj osebujnosti svoje jezične zajednice: u Hrvatskoj - saradnja v. suradnja, u Srbiji - suradnja v. saradnja), ili su se donosile nedosljedno i netočno. Tako su, primjerice, mnoge hrvatske i srpske istovrijednice $u$ rječničkim člancima dane bez ikakvih odrednica, kao niz istoznačnih parova: azot, dušik; bioskop, kino; fudbal, nogomet; juha, čorba, supa; kašika, žlica; kava, kafa; puran, tukac, ćuran i dr. Nepostojanje etnojezičnih odrednica u rječnicima stvaralo je određene teškoće pri odabiru istovrijednica. Primjerice, u Ivanovič-Petranovičevu rječniku uz riječ vozduh nalazimo istovrijednice: vazduh, zrak, uzduh (Ivanovič 1976:71). Ali, te istovrijednice nisu istoznačnice jer su leksičko-semantički razdvojene pa i stiliski obilježene. Riječ zrak (hrv.) u srpskom znači 'zraka svjetlosti', a ne 'vazduh'; uzduh se smatra zastarjelicom. U Stankovićevu rječniku uz rusku riječ britva nalazimo 'brijač, britva'; uz natuknicu značenie - 'važnost, značaj, vrednost'; uz riječ nalivat - 'liti, točiti, sipati', a riječ slavjanskij prevedena je istovrijednicama 'slovenski, slavenski' (Russko-serbskohorvatskij slovar 1988:55, 245, 383, 787). U hrvatskom jeziku pak riječ brijač znači ‘brijački obrtnik', a ne 'britva'; značaj 'skup duševnih svojstva', a ne 'smisao kojega znaka riječi ili pojave'; sipati 'istresati sipku stvar', a ne 'nalijevati ili točiti'; slovenski 'koji se odnosi na Slovence i Sloveniju', a ne na 'Slavene'.

Jezičnopolitički zaključci Novosadskoga dogovora uz ostalo su pojedincima, odnosno izdavačima ostavili pravo i mogućnost izbora tzv. varijante 
jezika kojom će se služiti tijekom svojega pisanja i tiskanja članaka i knjiga. Točka 8. Novosadskoga dogovora glasi: »Treba odlučno stati na put postavljanju veštačkih prepreka prirodnom i normalnom razvitku hrvatskosrpskog književnog jezika. Treba sprečiti štetnu pojavu samovoljnog 'prevođenja' tekstova i poštovati originalne tekstove pisaca«. U točki 8. zahtijeva se bezuvjetna sloboda za "prirodan i normalan razvoj hrvatskosrpskog književnog jezika«, kao i poštivanje izvornih, osebujnih autorskih tekstova. Svatko je na svoj način počeo ostvarivati poruke jezičnopolitičkoga dokumenta. Jedni su i dalje nastavili pisati onako kako su pisali prije, a bilo je i onih koji su tu "slobodu" počeli rabiti na svoj način razumijevanja jezika, u zabranjivanju "veštačkih prepreka", samovoljnoga "prevođenja" i poštivanja "originalnih" tekstova pisaca. U tijeku jugounitarističkoga pokušaja stvaranja jednoga i jedinstvenoga jezika Hrvata, Srba, Bošnjaka, i Crnogoraca pojavljuju se članci i knjige visokih državnih partijskih i vojnih dužnosnika koji su pisani mješavinom hrvatskih i srpskih norma. Riječ je o tzv. slobodnoj porabi različitih hrvatskih i srpskih počela u jednom te istom tekstu članka ili knjige. Tobožnja sloboda i ravnopravnost jezika u odnosu na poštivanje izvornika autorskoga teksta otvorila je vrata nepismenosti. Tako u knjigama Branka Mamule, umirovljenoga admirala flote, nalazimo istodobnu porabu hrvatskih i srpskih riječi koje redovito ne pripadaju ni jednoj stvarnoj normi dvaju jezika.

U njegovim knjigama vidljiva je neutralizacija polariziranih hrvatskih i srpskih riječi, poraba u svojstvu istoznačnica i inačica dubleta, kao što su: talijanski - italijanski, opći - opšti, također - takođe, utjecaj-uticaj, zaljevzaliv, kriterij - kriterijum, obalni-obalski, suvremeni uvjeti-savremeni uslovi, protupodmornički - protiopodmornički, angažirati - angažovati, organizirati - organizovati, vlastit - sopstven, vanjski-spoljni, u vezi s tim - u vezi sa tim i dr. Primjerice: »U većini ratnih mornarica ovo je kriterijum...«-»Kriterij za određivanje granica vojnopomorske oblasti [...] uzima u obzir...« (Mamula 1977:160, 252). »U savremenim uslovima doveli su...« - »Rat u suvremenim uvjetima sve je teže..." (Mamula 1985:73, 89). S jedne strane, autor rabi riječi koje se obično uvrštavaju u hrvatske: ocean, uopće, otok, tjedan, Španjolska i dr.; s druge pak strane srpske riječi: odbrana, milion, petrohemija, obim, oktobar, Kipar, Španija, Liban, vazduh, obezbijediti, snabdijevati i dr. U jednoj rečenici može se naći mješavina hrvatsko-srpskih riječi: »U našim uslovima geografski dobro raspoređen vanjski niz otoka pruža mogućnost da se linija vrlo snažne odbrane [...] da bez angažovanja...« (Mamula 1977:227-228).

I u govoru Josipa Broza Tita, kao i u Branka Mamule, vidljiva je djelomična neutralizacija međujezične polarizacije. U knjizi Vojna misao i djelo autor istodobno u svojstvu istoznačnica ili inačica rabi riječi i višerječnice, 
kao što su: uopće - uopšte, svećenstvo - sveštenstvo, slavenski narod - slovenski narod, barbarski - varvarski, protunarodni režim - protivnarodni režim, suvremeni - savremeni, također - takođe, Španjolska - Španija, Rumunjska - Rumunija, Talijani - Italijani, poduzeće - preduzeće, poduzeti-preduzeti, opskrba - snabdijevanje, dvjestomilijunski narod - dvestomilionski narod, vlastit - sopstven, tvornica-fabrika, historija, povijest - istorija, u vezi s tim-u vezi sa tim, organizirati-organizovati, vanjska politika - spoljna politika $i d r$. U jednom te istom tekstu možemo npr. sresti i Španjolska i Španija ili vanjska politika i spoljna politika. Usporedi: »Šta se događa u Španiji?« - »Španjolska [...] zaostala je...«. »Svojom izdajničkom spoljnom politikom on odvaja Jugoslaviju od njenih saveznika...« - -Vlada narodne sloge i odbrane treba da prekine sa izdajničkom vanjskom politikom..." (Tito 1982:25, 32).

Autori miješaju hrvatske i srpske norme stvarajući neki jezični srpskohrvatski koktel koji ne pripada ni hrvatskomu ni srpskomu standardu. U vrijeme bratstva, jedinstva i ravnopravnosti neutralizacija međujezične polarizacije i nepoštivanje norma ne samo da se dopušta nego i odobrava. Dakle, riječ je o svojevrsnom jezičnom nadomjestku, supstratu (miješanom ili "bastardnom", hrvatskosrpskom "novojeziku" socijalističkoga jugoslavenskoga razdoblja), pokušaju izdavača ili autora da se pridržava odluka Novosadskoga dogovora i zajedničkih pravopisnih pravila (1960.). I dok su se na tzv. Bečkom književnom dogovoru iz 1850. i 1920-ih i 1930-ih godina u monarhističkoj Jugoslaviji redovito nizali neuspjeli pokušaji normiranja uz pomoć unifikacije i daljnje kodifikacije jezika u korist ponajprije srpske norme te stvaranja tzv. "srpsko-hrvatsko-slovenačkoga" jezika, u socijalističkoj Jugoslaviji na djelu je nešto drukčija, ali ipak slična težnja da se ponovno kodificira "srpskohrvatski/hrvatskosrpski jezik", ali sada već u njegovim varijantnim ostvarajima ili s pomoću njihove neutralizacije (Bagdasarov 2012).

Uspostava privilegija pri porabi na državnoj razini jezika naroda koji prevladava, bez obzira na širinu njegove rasprostranjenosti i trajanje porabe u međuetničkoj i međukulturnoj komunikaciji, dovodi njegove nositelje u privilegirani položaj. Ostali jezici dolaze u prikliješten, stisnut položaj, funkcionirajući samo u granicama administrativno-teritorijalnih jedinica, subjekata federacije (republikâ, autonomnih pokrajina). Predstavnici nacionalne inteligencije izjavljuju da stvaranje "tzv. neovisnosti" (stvaranje stare buržujske i nove socijalističke Jugoslavije) znači samo promjenu imperijalnih ambicija novih gospodara. Prirodno je što se povremeno javljaju pokušaji nacionalne manjine da iziđe iz sastava višeetničke države i stvori svoju neovisnu državu s vlastitim etnolingvonimom (Bell 1980:219_ 220). Primjerice, u Sloveniji se u odnosu prema "srpskohrvatskomu" (srp- 
skomu) jeziku u JNA stvarala oporba u slovenske mladeži. Iznošeni su zahtjevi za izvođenjem jugoslavenske vojske iz Slovenije, porabom slovenskoga jezika u vojnim postrojbama i u nazivima vojnih objekata smještenih na slovenskom području (Pavić 1986:4).

Nerijetko bi u različitim raspravama jedna od suprotstavljenih strana nastojala iskoristiti nezadovoljstvo dijela svojega naroda u drugim federalnim jedinicama, izazvano, s njihova gledišta, nepravednim rješenjem jezičnoga pitanja. Tako su još na 5. kongresu slavista, održanom 1965. god. u Sarajevu, hrvatski jezikoslovci istupili s kritikom uklanjanja iz jezične porabe u Bosni i Hercegovini hrvatskih riječi i uvođenjem srpskih. To je bilo shvaćeno kao ograničivanje jezičnih prava Hrvata i Muslimana (Bošnjaka) koji su živjeli u toj višeetničkoj republici (Hraste 1966:112-113; Jonke 1971:28). Srpski pak lingvisti govore o neravnopravnom etnojezičnom i socijalnoekonomskom položaju Srba koji žive u Hrvatskoj (Ivić 1986:1751).

Nisu prestajale uzajamne optužbe zbog neporabe hrvatskih ili srpskih riječi. Kao primjer mogu poslužiti publikacije s raščlambom porabe hrvatskoga i srpskoga leksika u školskim udžbenicima Hrvatske i Srbije. Hrvatski školski udžbenici bili su kritizirani zato što u njima nema uobičajenih srpskohrvatskih riječi, a srpski za nepostojanje hrvatskoga leksika. U nekim udžbenicima, na primjer, kako piše F. Butorac u članku Nacionalizam $i$ jezik, uopće se ne rabe takve uobičajene riječi kao što su sistem, metal, muzika, kompozitor i dr. Umjesto njih dosljedno se uvode i rabe riječi sustav, kovina, glazba, skladatelj i dr. (Butorac 1985:19). S druge pak strane, u srpskim školskim udžbenicima, kako pokazuje Z. Diklić u članku Jezične istine i neistine, nema hrvatskoga leksika. Tako u srpskom rječniku nema riječi koje su u porabi u Hrvatskoj, kao što kruh, trokut, ravnalo, višekatnica, listonoša itd. U srpskim čitankama, piše Z. Diklić, rabe se samo riječi kao što su muzika, raspoloženje, a u hrvatskima glazba i muzika, krajolik i pejzaž, ugođaj, atmosfera i raspoloženje itd. (Diklić 1989:14-15).

Članci o pitanjima etnojezičnih odnosa periodično su se počeli pojavljivati u hrvatskom i srpskom tisku, što je svjedočilo aktualizaciji i neriješenosti toga važnoga socijalnopolitičkoga pitanja. Uz ostalo, pisalo se da u hrvatskim medijima i u izdavačkoj djelatnosti pri objavljivanju prijevoda iz stranih književnosti hrvatski prevoditelji i urednici često provode kampanju "čišćenja" književnoga jezika od "srbizama" ili "stranih posuđenica", »nedopuštene samovoljne porabe arhaizama i umjetno stvorenih riječi« (Dmitriev 1981:153-154; Malić 1988:42-44). Jezično čistunstvo u Hrvatskoj nije dobivalo tako masovan značaj, a nije ga ni mogao imati u doba vladavine SKJ-a, kako su to ponekad pokušavali prikazati pojedini novinari, partijski djelatnici ili jezikoslovci. Strana je književnost prevođena i u 
Hrvatskoj i u Srbiji, s time da su se uzimale u obzir različitosti etnojezičnih sredina i navike zajednica kojima je dati prijevod bio namijenjen. U uredništvu novina Borba (novine su izlazile u srpskoj i hrvatskoj inačici), a i u uredništvu zagrebačkih novina Vjesnik, pri objavljivanju istovjetnih vijesti (npr. Tanjugovih) prevodili su se tekstovi sa srpskoga na hrvatski ili su se jezično prilagođivali. Usp.:

\begin{tabular}{|l|l|}
\hline \multicolumn{1}{|c|}{ Srpski jezik } & \multicolumn{1}{|c|}{ Hrvatski jezik } \\
\hline $\begin{array}{l}\text { Prvi uslov je oslobađanje od do- } \\
\text { gmatskog shvatanja da je sve... } \\
\text { (Borba, 20./21. 9. 1986., 1) }\end{array}$ & $\begin{array}{l}\text { Prvi uvjet je oslobađanje od do- } \\
\text { gmatskog shvaćanja da je sve... } \\
\text { (Vjesnik, 20./21. 9. 1986., 2) }\end{array}$ \\
\hline $\begin{array}{l}\text { Savezni sekretar za inostrane po- } \\
\text { slove... i šef diplomatije... kon- } \\
\text { statovali su napredak... (Politika, } \\
\text { 1. 6. 1989., 2) }\end{array}$ & $\begin{array}{l}\text { Savezni sekretar za vanjske po- } \\
\text { slove... i šef diplomacije... kon- } \\
\text { statirali su napredak... (Vjesnik, } \\
\text { 1. 6. 1989., 1) }\end{array}$ \\
\hline $\begin{array}{l}\text { Predsednik Predsedništva } \\
\text { SFRJ... govoriće u Generalnoj } \\
\text { skupštini Ujedinjenih nacija (Po- } \\
\text { litika, 15. 9. 1989., 2) }\end{array}$ & $\begin{array}{l}\text { Predsjednik Predsjedništva } \\
\text { SFRJ... govorit će u Generalnoj } \\
\text { skupštini Ujedinjenih naroda } \\
\text { (Vjesnik, 15. 9. 1989., 1) }\end{array}$ \\
\hline
\end{tabular}

Tablica 1. Jezična prilagodba tekstova u dnevnom tisku

Bez obzira na demokratičnost poštivanja razlika između dvaju jezika, normiranje hrvatskoga i izradba različitih normativnih priručnika nastavlja se. Josip Silić i Dragutin Rosandić objavljuju 1974. god. Osnove fonetike i fonologije hrvatskoga književnog jezika, a 1979. god. Osnove morfologije i morfostilistike hravtskoga književnog jezika. Godine 1978. Zlatko Vince (1922. - 1994.) objavljuje knjigu pod nazivom Putovima hrvatskoga književnog jezi$k a$ o koncepcijama razvoja hrvatskoga književnoga jezika u filološkim školama 19. st. Godine 1979. hrvatski jezikoslovci objavljuju Praktičnu gramatiku hrvatskoga književnog jezika. U njoj su bile odsutne pojedine naglasne i morfološke istovrijednice koje su bile u porabi srpskoga jezika. Tako, na primjer, nisu navedene naglasne istovrijednice s tipom naglaska osobnih zamjenica u kosim padežima jedn.: gen. mène, dat. mèni itd.; nema upitnoodnosnih zamjenica $k o$, šta; nisu dane istovrijednice afiksâ: protiv-, sa-, van-, -ioni, -ista. Prerađenu Praktičnu gramatiku ponovno izdaju pod naslovom Gramatika hrvatskoga književnog jezika (1990.) i Hrvatska gramatika (1995.). Godine 1986. D. Brozović objavljuje rad pod nazivom Deset teza o hrvatskome jeziku. Na osnovi zajedničkoga "hrvatsko-srpskoga dijasistema" ugledni jezikoslovac teoretski razrađuje status hrvatskoga jezika. Iste godine S. 
Babić objavljuje knjigu Tvorba riječi u hrvatskom književnom jeziku, R. Katičić tiska Sintaksu hrvatskoga knjižeonog jezika, a V. Anić i J. Silić Pravopisni priručnik hrvatskoga ili srpskoga jezika.

»U ozračju Hrvatskoga proljeća 1971. godine«, zaključuje Nataša Bašić, »četiri su hrvatske znanstvene i kulturne ustanove otkazale Novosadski dogovor kao velikosrpski jezični akt uperen protiv samobitnosti, slobode i naravnoga razvitka hrvatskoga jezika: MH s Jonkeom na čelu (16. travnja), HFD (8. svibnja), Institut za jezik JAZU (10. svibnja) i DKH (1. srpnja). Iako su već u prosincu 1971. demokratski procesi u Hrvatskoj zaustavljeni, Matici zabranjen rad, Jonke 1973. umirovljen, a mnogi hrvatski intelektualci zatvoreni na dugogodišnje zatvorske kazne, protuunitaristički jezikoslovni smjer u Hrvatskoj ipak je pobijedio: u ustavne amandmane 1971. i u hrvatski Ustav 1974. ušla je odredba "hrvatski književni jezik" "(Bašić 2007:171).

\section{Od Zagrebačkoga dogovora 1986. do državnoga i jezičnoga raspada 1991.}

Centralni komitet Saveza komunista Hrvatske (1985.) još je jednom pokušao stabilizirati međuetničke jezične odnose te centralizirati etnojezičnu politiku na području Hrvatske. Predsjedništvo je CK SKH usvojilo na svojoj sjednici 2. prosinca 1985. god. dokument pod naslovom Stavovi o aktualnim pitanjima jezične politike. Zaključci tih radnih partijskih sastanaka održanih 1985./86. god. kasnije su popularno nazivani Zagrebački dogovor. U odlukama sa sjednice isticalo se da je potrebno osigurati ravnopravnost i podupirati snošljivost u porabi hrvatskoga i srpskoga jezika, uzajamno zbližavanje naroda i narodnosti, daljnji razvoj socijalističke revolucije, jačanje radničke klase u SR Hrvatskoj. »Sada, kada naše društvo«, kaže se u rezoluciji CK SKH,

»nailazi na mnoge ekonomske i političke poteškoće, kada se sve češće čuju glasovi protivnika samoupravne socijalističke Jugoslavije, osnovane na bratstvu i jedinstvu, pojačava se nacionalističko djelovanje na području jezika. Nije stoga slučajno da se glavna strateška linija, osobito hrvatskog nacionalizma, stalno očituje u pokušajima opovrgavanja znanstvenih činjenica da Hrvati, Srbi, Crnogorci i Muslimani govore jednim jezikom, koji u različitim društvenim i nacionalnim sredinama ima svoje posebnosti i ostvaruje se u varijantnim standardiziranim oblicima (Kočiš 1989:12).

Predsjedništvo CK SKH odlučno je osudilo kako pojavu separatizma tako i unitarizma na području jezika. Zadana je hitna zadaća da se na- 
piše pravopis i nastavi izdavanje Rječnika hrvatskosrpskoga jezika (Babić 1990:177-185).

U Zagrebu 4. veljače i 18. travnja 1986. god. održano je radno savjetovanje predsjedništava centralnih komiteta SK Bosne i Hercegovine, Crne Gore, Hrvatske, Srbije i pokrajinskih komiteta SK Kosova i Vojvodine, na kojem su sudjelovali i jezični stručnjaci (iz Hrvatske V. Anić i J. Silić, iz Bosne i Hercegovine M. Šipka), predstavnici znanstvenih, kulturnih i obrazovnih ustanova. Na savjetovanju su prihvaćeni Zaključci Zagrebačkoga dogovora, u biti: program jezične politike SKJ. U prvom dijelu Zaključaka data je kratka ocjena međuetničkih jezičnih odnosa. U drugom dijelu pokazane su i negativne i pozitivne tendencije $u$ razvoju jezika; $u$ trećem su naznačeni putevi izlaza iz nastale jezične situacije. Navest ćemo u općim crtama sadržaj glavnih stavova Zaključaka:

- teorijski razraditi i ideološki obrazložiti opći stav o statusu standardnoga jezika Hrvata, Srba, Crnogoraca i Muslimana u njegovim varijantnim ostvarajima

- uvesti i širiti dane stavove u svim sferama društvenoga života, kritički razmotrivši ostvarivanje jezične politike u nastavnim programima, udžbenicima i priručnicima, medijima, u uredničkoj i izdavačkoj djelatnosti

- pravno urediti status jezika i njegov naziv u Ustavu SFRJ, u ustavima republika i pokrajina

- ponovno razmotriti i uskladiti oblike ostvarivanja ravnopravnosti inačica jezika u Skupštini SFRJ, saveznim organima i društveno-političkim organizacijama

- pojačati znanstvenoistraživački rad na području jezika; s tim ciljem pozornost usmjeriti na pripremu kadrova, poglavito mladeži orijentirane na marksističku ideologiju i postignuća suvremene marksističke misli

- kodificirati jezik: pripremiti novi nacrt pravopisnih pravila, uz privlačenje u razmatranje toga pitanja širokih slojeva društva; izdati jednosveščani rječnik, znanstvenu gramatiku; urediti i standardizirati stručno i znanstveno nazivlje; nastaviti rad na izdavanju rječnika suvremenoga srpskohrvatskoga standardnoga jezika na latinici

- podići razinu jezičnoga obrazovanja i širiti kulturu govora

- formirati odgovarajuće organe za pitanja jezika i jezične politike pri Centralnom komitetu komunista i republičkim komitetima Socijalističkoga saveza radnoga naroda Jugoslavije (Babić 1990:165-185).

Cilj jezične politike centralnih i republičkih organa SKJ bio je, s jedne strane, pojačati ulogu partijske državne vlasti u svim područjima društve- 
noga života, uključujući i jezik, a s druge pak strane, oslabiti etnojezičnu napetost, unificirati i kodificirati jedan jezik u njegovim varijantnim ostvarajima.

Promjena socijalnopolitičkih prigoda, jezične politike i službenoga lingvonima (hrvatskosrpski, hrvatski ili srpski, hrvatski jezik) neposredno ili posredno utječe na distribuciju i funkcioniranje polariziranoga hrvatskoga i srpskoga leksika. Pogledat ćemo, primjera radi, u vremenskom slijedu odabir istovrijednoga niza u različitim izdanjima rječnikâ F. R. Poljanca i S. M. Madatove-Poljanec: Rusko-hrvatskosrpski rječnik (Zagreb 1962.), Rusko-hrvatski rječnik (Zagreb 1966.), Rusko-hrvatski rječnik (Zagreb 1973.), Rusko-hrvatski ili srpski rječnik (Zagreb 1987.). Prvo izdanje toga rječnika u izdavačkoj kući Školska knjiga izišlo je još 1962., a 2002. god. pretisak prvoga prerađenoga izdanja (1987.). Obratimo pozornost kako se mijenja naslov nekoliko izdanja istoga dvojezičnika s različitim lingvonimima i istodobno s njim istoznačne istovrijednice ovisno o jezičnopolitičkoj situaciji u ondanjoj Hrvatskoj. U Poljančevu Rusko-hrvatskosrpskom rječniku (1962., 1966.) nakon Novosadskoga dogovora iz 1954. god. nalazimo: biber, papar; kamila, deva; kava, kafa; partija, stranka; učesnik, sudionik; škare, makaze; žohar, bubašvaba itd.; u njegovu Rusko-hrvatskom rječniku (1973.) nakon maspoka: papar, biber; deva; kava; stranka, partija; sudionik, učesnik; škare, nožice; žohar itd.; a u njegovu Rusko-hrvatskom ili srpskom rječniku (1987.) nakon Zagrebačkoga dogovora 1986.: papar, biber; deva, kamila; kava; stranka, partija; sudionik, učesnik; škare, makaze, nožice; žohar, bubašvaba itd. Odvojene se nehrvatske ili nestandardnojezične riječi iz 1960-ih godina ponovno vraćaju u 1980-te godine. Navest ćemo još nekoliko očitih primjera. U Poljančevu dvojezičnom rječniku (1973.) nalazimo samo hrvatske riječi: dušik, kazalište, kino, liječnik, otok, riža, sigurnost, stupanj, vlak, žlica i sl., a u dvojezičniku (1987.) se nalaze istovrijednice: dušik, azot; kazalište, glumište, pozorište; kino, bioskop; liječnik, ljekar; otok, ostrvo; riža, pirinač; sigurnost, bezbjednost; stupanj, stepen; vlak, voz; žlica, kašika i sl. Naslov, leksik i red riječi u dvojezičniku tijesno su povezani s jezičnopolitičkom situacijom na hrvatskom jezičnom području. U doba "bratstva i jedinstva" dvojezičnik rječničkom građom pokriva i srpsku i hrvatsku sastavnicu, u razdoblju odmah nakon hrvatskoga proljeća (1971.) nalazimo samo hrvatske riječi, a u doba ponovnoga povratka na staro, tj. "dogovorene lingvistike" (izraz M. Petija) iznova susrećemo tzv. hrvatske i srpske inačice. Ako usporedimo Poljančev Rusko-hrvatski ili srpski rječnik (1987.) s Rusko-srpskohrvatskim rečnikom (1988.) u redakciji Bogoljuba Stankovića (Moskva - Novi Sad, 1988.), vidjet ćemo jednaku rječopisnu koncepciju rječničkoga "zajedništva" u kojem je samo redoslijed istovrijednica premješten: azot, dušik; pozorište, ka- 
zalište; bioskop, kino; lekar, liječnik; ostrvo, otok; pirinač, riža; bezbednost, sigurnost; stepen, stupanj; voz, vlak; kašika, a riječi žlica uopće nema u tom rječniku. Uzgred valja reći da je Poljanec bio i autor udžbenikâ Istorija srpskohrvatskoslovenačkog jezika s pregledom naših dijalekata $i$ istorijskom čitankom (Beograd 1931. - Zagreb 1936.) i Pregled istorije srpsko-hrvatskog književnog jezika (Sarajevo 1929.). Zanimljivo je da su u Stankovićevu Rusko-srpskom $i$ srpsko-ruskom rečniku 2015. god., u usporedbi npr. s Rusko-srpskohrvatskim rječnikom 1988. god., izbrisane sve hrvatske riječi i navedene samo srpske: bezbednost, decembar, fabrika, hleb, fudbal, istorija, italijanski, kašika, organizacioni, pozorište, sprat, železnička stanica itd. (Stanković 2015). Tijekom izjednačivanja hrvatskoga i srpskoga jezika dio hrvatske leksičke baštine jezični unitaristi ukidaju kao "staru ideologiju buržujskoga režima" ili "ustaštva", dio kodificiraju "po srpskosti" (npr., vojno i pravno nazivlje), a dio neutraliziraju stvaranjem srpskohrvatskih istoznačnica. Porabu jedne skupine hrvatskih riječi zabranjuju ili kažnjavaju, a iz druge skupine stvaraju često "jezičnu mješavinu" uz pomoć potkopavanja jezičnih norma (ili jezične erozije), uključujući ju u različite standardnojezične tekstove i priručnike. Jezične agresije u doba obiju Jugoslavija bilo je podosta - ljudi su zbog hrvatskih riječi smjenjivani, otpuštani, osuđivani, zatvarani, proganjani... (Bagdasarov 2015:155).

Godine 1988., 7. prosinca, Ustavni sud SFRJ-a usvojio je odluku o neustavnosti 1. točke 138. članka Ustava SR Hrvatske gdje je riječ o porabi i nazivu hrvatskoga književnoga jezika. Temeljem za takvu odluku bila je, po mišljenju sudaca Ustavnoga suda SFRJ-a, povreda prava srpskoga stanovništva Hrvatske jer naziv "hrvatski književni jezik" ništa ne govori o tom da pripada (i) Srbima. Pokušaj hrvatskoga Sabora da pomoću 41. amandmana promijeni formulaciju 138. članka Ustava SR Hrvatske izazvao je val prosvjeda društvenih organizacija, znanstvenih društava i ustanova (Društvo hrvatskih književnika, Institut za jezik Jugoslavenske akademije znanosti i umjetnosti, Hrvatsko filološko društvo, Filozofski fakultet Sveučilišta u Zagrebu i dr.). Hrvatske društvene organizacije i znanstvena društva ponovno su istupili protiv »kršenja ustavnih jezičnih prava hrvatskoga naroda na samostalan razvitak, vlastiti naziv i porabu hrvatskoga jezika«. Slični masovni pokreti za obranu materinskoga jezika bili su viđeni, kako je već rečeno, koncem 1960-ih i početkom 1970-ih godina u doba porasta nacionalnoga pokreta i objavljivanja poznate Deklaracije o nazivu i položaju hrvatskoga književnoga jezika. Hrvatski Sabor je poslije dugih rasprava odbio 41. ustavni amandman u kojem se govori o »... službenoj uporabi hrvatskoga ili srpskoga jezika...«. 
Zahtjeve za određivanje i davanje pravnih i socijalnoekonomskih jamstava za zaštitu upravo hrvatskoga jezika društvene organizacije, znanstvene i kulturne ustanove Hrvatske rabile su i za unutaretničko i unutarjezično združivanje (konsolidaciju) stanovništva. Privrženost kulturi i povijesti upravo hrvatskoga jezika toliko se osjeća u hrvatskoj etnolingvokulturnoj zajednici da je ona ne samo određivala iskorištavanje date jezične tvorevine u sociokulturne i etnopolitičke svrhe, nego je i uvjetovala njezino izdvajanje iz sastava srpskoga jezika, potičući njezin divergentan razvoj i daljnju kodifikaciju.

Koncem 1980-ih godina u Srbiji se objavljuju članci o opasnosti da ćirilicu istisne latinica i o potrebi da se poduzmu konkretne mjere za zaštitu ćirilice (Potreba zaštite ćirilice 1988:8-10; Lukić 1989:15; Stojanović 1989:1415). Neki Srbi i Crnogorci ćirilicu poistovjećuju s etničkom pripadnošću, čak i s pravoslavljem, a latinicu s nečim što je tuđe vlastitoj kulturi, s nečim stranim, s katolicizmom. Zaštita vlastitoga pisma i s njima povezane raspre postojale su u prošlosti i u Hrvata. Tako je u veljači 1935. god. u okolici Slavonskoga Broda došlo do seljačkih nemira, izazvanih zatvaranjem nekolicine seljaka iz sela Sibinj, optuženih za "antidržavnu agitaciju". Bili su krivi samo zato što su pokušali skinuti natpise napisane ćirilicom, budući da se stanovništvo Hrvatske od davnine služi latinicom (Sumarokova 1980:116). »Pismo - to su svojevrsni znakovi prepoznavanja za etnovjersko samoodređivanje naroda, njegovih kulturnopolitičkih smjerokaza i težnja « (Mečkovskaja 1998:76).

Već je koncem 1960-ih i početkom 1970-ih godina jezična politika na području Hrvatske i Srbije imala djelomično necentralizirano obilježje i različite parametre. Za Srbiju je u većoj mjeri bila svojstvena retrospektivnost jezične politike. Njezine su mjere bile usmjerene uglavnom na očuvanje postojećega jezičnoga stanja i jezičnoga sustava razrađenoga odlukama Novosadskoga dogovora. Retrospektivnost je bila motivirana nužnošću očuvanja neprekidnosti jezičnoga jedinstva Srba, Hrvata, Crnogoraca i Muslimana (Bošnjaka). Za Hrvatsku je pak bila svojstvena perspektivnost jezične politike. Njezine su mjere bile usmjerene na promjenu onodobnoga jezičnoga stanja, na izdvajanje hrvatskoga jezika i njegovih norma. Treba reći da su pri raspadu jedinstvene federativne države upravo Srbija i Crna Gora istupale za očuvanje Federacije, dok su Hrvatska i Slovenija bile za konfederativni poredak zemlje. Pokušaji da se ojača i učvrsti uloga centra prihvaćanjem amandmana na Ustav SFRJ-a 1988. god. nisu dali željeni rezultat. U provedbi jezične politike hrvatski jezik je često, na veliku žalost, podsjećao na njihalo koje se ljulja sad na jednu, sad na drugu stra- 
nu, od pokušaja spajanja (integracije) do razlikovanja (etnizacije, diferencijacije) i obratno.

Hrvatska se u cjelini zalagala za stvaranje vlastite države, a Srbija, u ime organa vlasti Federacije, za očuvanje i jačanje federativnoga ustroja zemlje. Jedan dio hrvatske inteligencije nastojao je očuvati etnolingvokulturnu posebnost vlastitoga društva, zalažući se za posebne nazive i odvojen razvoj hrvatskoga i srpskoga jezika. Drugi dio srpske i hrvatske inteligencije, naprotiv, nastojao je oslabiti, prikriti etnolingvokulturnu raznolikost različitih naroda na jugoslavenskom jezičnom prostoru, zalažući se za kontinuitet "srpskohrvatskoga" jezika i njegovu pripadnost i Hrvatima i Srbima. Ideje i pokušaji spajanja hrvatskoga i srpskoga jezika nisu se podudarali s nastojanjem hrvatske strane da čuva i razvija samostojnost i samostalnost vlastitoga jezika kao jednu od bitnih sastavnica identiteta. Srpska i hrvatska jugoslavensko orijentirana strana tumačila je hrvatske težnje za stvaranjem vlastite neovisne države i očuvanjem vlastitoga jezika kao očitovanje područnoga "separatizma" i "etnojezičnoga nacionalizma". Hrvatska je strana srpske težnje za jedinstvenom državom i unificiranjem jedinstvenoga jezika doživljavala kao očitovanje jugoslavenskoga "unitarizma" i "etnojezične diskriminacije i asimilacije". Kao što se vidi, cilj i zadaće stranâ u jezičnopolitičkom supostojanju i sukobu bili su potpuno suprotni. U uvjetima opće dezintegracije i decentralizacije jedinstvene države raspad je šestočlane federacije (SFRJ) postao neizbježan, a zajedno s njim i pokušaji daljnjega spajanja i izjednačivanja hrvatskoga i srpskoga u jedan jezik. »Stvar je u tom «, piše G. P. Neščimenko, »da ni izdaleka bilo koji etnos u ime ideje integracije nije spreman odustati od svojega vlastitoga, povijesno zauzetoga mjesta u svjetskom kulturnom prostoru, tj. od iskonskih kulturnih tradicija, jezične osebujnosti, etničke samosvijesti, tj. svega toga što ima za taj narod neprolazno značenje« (Neščimenko 2014:273).

U siječnju 1990. god. u Beogradu je održan posljednji, 14. kongres SKJa. Slovensko, a zatim i hrvatsko izaslanstvo, napustili su kongres zbog neslaganja o putevima daljnjega razvoja partije i njezine uloge u životu zemlje. SKJ je zapravo prestao postojati. Zemlja je naglo prešla iz jednopartijskoga u višestranački politički sustav. Mnoge nacionalne političke stranke i pokreti počeli su isticati parole o preustroju i razjedinjavanju zemlje. Međuetnički rat, koji je počeo u raznim krajevima zemlje, imao je tragične posljedice za sve narode bivše Jugoslavije i potpuno je pokopao nade u bilo kakvu mogućnost očuvanja jedinstvene države.

25. lipnja 1991. god. Hrvatska (Republika Hrvatska) i Slovenija (Republika Slovenija) službeno su proglasile svoju neovisnost, a 1992. god. bila 
je proglašena Savezna Republika Jugoslavija (SRJ) koja se sastojala od dviju republika - Srbije i Crne Gore. Godine 1990., 22. lipnja, Sabor Republike Hrvatske i 17. travnja 1992. Skupština SRJ-a usvojili su nove ustave svojih zemalja. Prema 12. članku Ustava Republike Hrvatske iz 1990. »u Republici Hrvatskoj u službenoj je uporabi hrvatski jezik i latinično pismo «(Ustav SRH 1990), a prema 15. članku Ustava SRJ iz 1992. »u Saveznoj Republici Jugoslaviji u službenoj upotrebi je srpski jezik ekavskog i ijekavskog izgovora i ćirilično pismo,..." (Ustav SRJ 1992).

Dakle, unutardržavna dezintegracija, raspad SFRJ-a i stvaranje novih država na postjugoslavenskom prostoru nisu se mogli neodraziti na jezičnu situaciju, divergentni razvoj i porabu jezika Hrvata, Srba, Crnogoraca i Bošnjaka (Muslimana). Traženje uzajamno prihvatljivih rješenja za reguliranje etnojezičnih nesuglasja, za normiranje i kodifikaciju književnoga (standardnoga) jezika navedenih etnosa potpisivanjem Novosadskoga (1954.) i Zagrebačkoga dogovora (1986.), nisu dovele strane do zajedničkoga jezičnoga usuglašavanja i stvaranja jednoga kodificiranoga "srpskohrvatskoga/hrvatskosrpskoga" jezika. Književni (standardni) hrvatski i srpski jezik u nastaloj sociolingvističkoj situaciji u Hrvatskoj i Srbiji stekli su konačni, vlastiti i pravni status te se počeli razvijati samostalno (Bagdasarov 2010).

\section{Zaključak}

Etnojezična politika u jezičnoj izgradnji zajedničkoga jezika na hrvatsko-srpskom etnolingvokulturnom govornom području nakon Drugoga svjetskoga rata i stvaranja Socijalističke Federativne Republike Jugoslavije odvijala se $u$ daljnim pokušajima integracije i diferencijacije jezika Hrvata, Srba, Bošnjaka (Muslimana) i Crnogoraca. Etnojezična integracija izražavala se, ponajprije prema hrvatskomu jeziku, putem istiskivanja njegovih etnojezičnih osebujnosti i posebnosti te izjednačavanjem sa srpskim jezikom, stvaranjem ili pokušajima stvaranja jednoga etnolingvonima, kodificiranoga zajedničkoga pravopisa i unifikacijom leksika. U prvoj fazi izgradnje nove federativne socijalističke jugoslavenske države na čelu s KPJ/SKJ-om etnojezična se politika zasnivala na ravnopravnosti narodâ i jezikâ čija su načela bila određena još na 2. zasjedanju AVNOJ-a 1943. god. u Jajcu. U novom ustavu FNRJ-a 1946. god. proglašena je ravnopravnost i samostalnost četiriju jezika: hrvatskoga, srpskoga, slovenskoga i makedonskoga. Sredinom 1950-ih godina etnojezična politika postupno poprima sve jači političku i kulturnoideološku narav, ponovno se javlja koncepcija o potrebi spajanja i unifi- 
kacije jezika, ponajprije Hrvata i Srba u korist "srpskohrvatskoga/hrvatskosrpskoga" (srpskoga), što je na kraju rezultiralo potpisivanjem Novosadskoga dogovora 1954. god. te izradbom zajedničkoga pravopisa i početak sastavljanja općega rječnika. Rast jezičnoga jugounitarizma u odnosu na hrvatski jezik i opasnost daljnje etnojezične asimilacije te gubitak vlastite etnolingvokulture izazvali su 1967. god. usvajanje Deklaracije o nazivu i položaju hrvatskog knjižeonog jezika. Deklaracija i njezin utjecaj na kasnija zbivanja, ponajprije na prekid izdavanja Rječnika dviju Matica, na otkazivanje Novosadskoga dogovora, tiskanje hrvatskoga pravopisa ("londonac"), a na kraju i na ustavnu promjenu iz 1974. god. naziva i statusa hrvatskoga jezika izazvali su daljnju međujezičnu divergenciju i na kraju autonomno razvijanje hrvatskoga i srpskoga jezika. Jugoslavenski unitaristički nauk marksističkoga internacionalizma na kraju krajeva pretvorio se u svoju suprotnost $-\mathrm{u}$ ideje etnolingvokulturnoga, gospodarstvenoga i državnoga razmeđivanja i razdvajanja.

U drugoj Jugoslaviji nastavio se unitaristički pokušaj oblikovanja srpskohrvatskoga/hrvatskosrpskoga jezika kao središnjega jugoslavenskoga jezika uz pomoć dogovorne lingvistike koja se iskazivala u stvaranju unificiranoga pravopisa i dogovorom oko sastavljanja općega rječnika. Unificirani leksik nastojalo se postići neutralizacijom međudržavnih leksičkih razlika putem stvaranja istoznačnoga ili inačičnoga niza hrvatskih i srpskih riječi, preoblikom pojedinih neutralnih hrvatskih riječi u stilski obilježene, postupkom uspostave leksičke norme $u$ korist ponajprije srpskoga jezika, hibridnom porabom leksičke i gramatičke hrvatsko-srpske jezične mješavine (tzv. jezične egalizacije) u priručnicima i tekstovima. Diferencijacija (etnizacija) se izražavala pokušajima hrvatske strane da očuva vlastiti etnolingvonim i samostalan razvoj hrvatskoga književnoga (standardnoga) jezika putem otpora, protudjelovanja jezičnomu jugounitarizmu uz pomoć daljnje kodifikacije hrvatskoga jezika stvaranjem vlastitih normativnih priručnika. Unutarjugoslavenska dezintegracija, otpor jezičnomu unitarizmu, raspad SFRJ-a i obrazovanje u Republici Hrvatskoj omogućili su hrvatskomu jeziku neovisan i samostalan razvoj.

Međutim, i danas postoji međunarodna skupina aktivista i dio jezikoslovaca koji ponovno pokušavaju osporiti samosvojnost različitih jezika na postjugoslavenskom prostoru, kao i pravo na vlastiti etnolingvonim i poseban razvoj u sklopu Bosne i Hercegovine, Crne Gore, Hrvatske i Srbije. U Sarajevu je 30. ožujka 2017. god. objavljena tzv. Deklaracija o zajedničkom jeziku. Deklaracija ili sarajevski bchs manifest o zajedničkom jeziku izazvao je oštre kritike od strane hrvatskih državnih dužnosnika, HAZU-a, javnih 
i strukovnih jezikoslovnih djelatnika.

Hrvatski jezik postao je 24. službeni jezik u EU-u, ali tzv. radni jezici Europskoga povjerenstva i upravnih tijela ipak su samo engleski, francuski i njemački. Teško je prognozirati kako će se razvijati hrvatski jezik kao jedan od službenih u globalnoj europskoj zajednici među državama i jezicima koji imaju različit povijesni, politički, gospodarski, kulturni i sociolingvistički status, pa i vlastite tradicije etnoligvokulturne baštine u EU-u, u uvjetima odsutnosti jezičnoga zakona u Hrvatskoj koji bi ga branio u svim pojavnostima. U zadnje vrijeme sve više zemalja EU-a izražava zabrinutost za sudbinu svoje etnokulture i predlažu hitnu preobliku globalizacije $\mathrm{u}$ korist etnizacije i suverenosti.

\section{Literatura}

Auburger, Leopold. 2009. Hrvatski jezik i serbokroatizam. Rijeka: Maveda HFDR.

Babić, Stjepan. 1990. Hrvatski jezik u političkom vrtlogu. Zagreb: Ante Pelivan i Danica Pelivan.

Babić, Stjepan. 2009. Hrvatski jezik za komunističkoga razdoblja. Jezik, 3, 106-114.

Bagdasarov, Artur R. 2004. Istorija razvitija horvatsko-serbskih etnojazykovyh otnošenij (1940-e-1990-e gg. XX v.). Slavjanskij vestnik Vyp. 2. K 70-letiju V. P. Gudkova. M.: MAKS Press, 30-49.

Bagdasarov, Artur R. 2010. Hrvatski književni jezik i njegova norma. Rijeka: Maveda - HFDR.

Bagdasarov, Artur R. 2012. Jezik kojim nitko nikad nije govorio. Vijenac, 470, 8. ožujka. http://www.matica.hr/vijenac/470/Jezik\%20kojim\%20 nitko\%20nikad\%20nije\%20govorio\%20/ (pristupljeno 29. 6. 2018.)

Bagdasarov, Artur R. 2015. Etnolingvokulturni razlikovnik Marka Samardžije. Recenzija. Kolo, 4, 153-160.

Bagdasarov, Artur R.; Milan Nosić. 2015. Materinski jezik - brana jezičnoj globalizaciji. Jezik, 62/4, 141-145.

Bašić, Nataša. 2007. Ljudevit Jonke i jugoslavenski jezični unitarizam. Je$z i k, 54 / 5,161-173$.

Batović, Ante. 2010. Zapadne reakcije na objavu Deklaracije o nazivu i položaju hrvatskog književnog jezika 1967. godine. Časopis za suvremenu povijest, 3, 579-594.

Bromlej, Julian V. 1983. Očerki teorii etnosa. Moskva: Nauka.

Brozović, Dalibor. 1969. Rječnik jezika ili jezik rječnika: varijacije na temu varijanata. Zagreb: Nakladni zavod MH. 
Butorac, Franjo. 1985. Nacionalizam i jezik. Komunist. 5. jula.

Černyšev, Vladimir A. 1978. Dinamika jazykovoj situacii v Severnoj Indii. Moskva: Nauka.

Deklaracija o nazivu i položaju hrvatskog književnog jezika: Građa za povijest Deklaracije. 1997. Ur. Hekman, Jelena. 3. izm. i dop. izd. Zagreb: Matica hrvatska.

Diklić, Zvonimir. 1989. Istine i neistine. Vjesnik: Panorama subotom. 23. prosinca, 14-15.

Dmitriev, Petr A. 1981. Dvujazyčnyj slovar' jazyka pisatelja i variant literaturnogo jazyka (na primere slovarja I. Andriča). Očerki leksgrafii jazyka pisatelja: Dvujazyčnye slovari. Leningrad: Izdael'stvo Leningradskogo universiteta, 130-157.

Dogovor o jeziku i pravopisu 8. XII. 1954. Vjesnik. 1989. 8. prosinca, 2.

Finka, Božidar. 1966./67. I jedinstvo jezika i književne varijante. Jezik, 3, 69-70.

Gak, Vladimir. 1989. K tipologii form jazykovoj politiki. Voprosy jazykoznanija, 5, 104-133.

Hraste, Mate. 1952. Dr. Dragutin Boranić: Pravopis hrvatskoga ili srpskoga jezika, deseto izdanje, Zagreb, 1951. Jezik, 1, 31-32.

Hraste, Mate. 1966. O trećoj varijanti hrvatskog književnog jezika. Jezik 4, 106-113.

Ivanovič Dušanovič, Slobodan; Iosif Petranovič Martinovič. 1976. Russkoserbskohorvatskij slovar'. Moskva: Russkij jazyk.

Ivić, Pavle. 1986. Razvoj književnog jezika na srpskohrvatskom jezičkom području. Knjižeonost, 10, 1743-1751.

Izvršni komitet CK SKH i CK SKS o suvremenoj jezičnoj problematici. 1968. Jezik, 3, 65-67.

Jonke, Ljudevit. 1971. Hrvatski knjižeoni jezik 19. i 20. stoljeća. Zagreb: Matica hrvatska.

Kameneckij, Vladilen M. 1985. Osnovnye etapy stroitel'stva socialističeskogo obščestva v SFRJ. Socialističeskaja Federationaja Respublika Jugoslavija. Moskva: Nauka, 9-25.

Karadža, M. 1991. Konstitucionnye aspekty jazykovoj problematiki. Funkcionirovanie jazykov v mnogonacional'nom obščestve. Moskva: Nauka, 310-324.

Kočiš, Mate. 1989. Jezik i Ustav. Vjesnik, 24. svibnja - 13. lipnja.

Lalević S., Miodrag. 1963. Srpskohrvatski u mom džepu, knj. 1-3. Beograd: Branko Đonović.

Lukić, R. D. 1989. Ćirilica u amandmanima na Ustav SR Srbije. Politika, 15, 14. januara, 15. 
Malić, Zdravko. 1988. Jezik pod osobitim nadzorom. Danas, 338, 9. kolovoza.

Mamula, Branko. 1977. Mornarice na velikim i malim morima. Beograd: Vojnoizdavački zavod.

Mamula, Branko. 1985. Savremeni svijet i naša odbrana. Beograd: Vojno-izdavački zavod.

Mečkovskaja, Nina B. 1998. Jazyk i religija. Moskva: FAIR.

Mečkovskaja, Nina B. 2001. Obščee jazykoznanie: Strukturnaja i social'naja tipologija jazykov. Moskva: Flinta-Nauka.

Mihajlovič, Kosta. 1986. Èkonomičeskaja dejstvitel'nost Jugoslavii. Moskva: Èkonomist.

Moskovljević, Miloš. 1963. Rečnik ruskog i srpskohrvatskog jezika. Beograd: Naučna knjiga.

Neščimenko, Galina P. 2014. Jazykovaja politika i nekotorye aspekty ejo interpretacii. Aktualjnye etnojazykovye $i$ etnokuljturnye problemy sovremennosti. Kniga 1. Moskva: Fond "Razvitija fundamentaljnyh lingvističeskih issledovanij", 258-285.

Odluka AVNOJ-a o upotrebi jezika 1989. Vjesnik, 19. siječnja, 2.

Pavešić, Slavko i dr. 1971. Jezični savjetnik s gramatikom. Zagreb: Matica hrvatska.

Pavičić, Josip. 1991. Dnevnik deklaracijskih zbivanja. Ur. Babić, Stjepan, Dalibor Brozović i Josip Pavičić. Deklaracija o hrvatskome jeziku s prilozima i Deset teza. Zagreb: Matica hrvatska, 19-24.

Pavić, N. 1986. Htjeli bi i etnički čistu JNA. Vjesnik, 25. travnja.

Potreba zaštite ćirilice. 1988. Naš jezik, 1-2, 8-10.

Pranjković, Ivo. 1998. Hrvatski standardni jezik u staroj Jugoslaviji (na primjeru časopisa Naš jezik). Croatica: prinosi proučavanja hrvatske književnosti, 45-46, 147-155.

Predlog za razmišljanje 1967. Borba, 3. aprila, 5.

Rendić, Smiljana. 2012. Izlazak iz genitiva ili drugi hrvatski preporod. HKV, 13. rujna. http://www.hkv.hr/vijesti/dokumenti/12768-smiljana-preporod.html. rendic-izlazak-iz-genitiva-ili-drugi-hrvatski-preporod.html.

Russko-serbskohorvatskij slovar'. 1988. Pod redakciej B. Stankoviča. Moskva - Novi Sad: Russkij jazyk - Matica srpska.

Selak, Ante (ur.). 1992. Taj hrvatski. Zagreb: Školske novine.

Stanković, Bogoljub. 2015. Rusko-srpski i srpsko-ruski rečnik. Beograd: Zavod za udžbenike.

Stojanović, M. 1989. Pismo i srpski Ustav. Vjesnik: Panorama subotom, 11. ožujka, 14-15. 
Sumarokova, Maja M. 1980. Demokratičeskie sily Jugoslavii v bor'be protivreakcii i ugrozy vojny 1929-1939. Moskva: Nauka.

Škiljan, Dubravko. 1988. Jezična politika. Zagreb: Naprijed.

Ujčić, Tugomir. 1952. Zapadna i istočna varijanta hrvatskosrpskog književnog jezika u školama. Jezik, 5, 148-152.

Ustav Federativne Narodne Republike Jugoslavije 1955. Beograd: Sužbeni list FNRJ.

Ustav Federativne Narodne Republike Jugoslavije 1957., 3. ijek. izd. Beograd: Službeni list FNRJ.

Ustav Republike Hrvatske 1990. Narodne novine. Službeni list Republike Hrvatske. http://narodnenovine.nn.hr/clanci/sluzbeni/1990_12_56_1092.html.

Ustav Savezne Republike Jugoslavije 1992. Službeni list SRJ", br.1/92., http://eudocitizenship.eu/NationalDB/docs/MON\%20FRY\%20ustav\%20 srj\%201992.pdf.

Ustav Socijalističke Federativne Republike Jugoslavije 1964., dop. izd. Beograd: Službeni list.

Ustav Socijalističke Federativne Republike Jugoslavije, Ustavi socijalističkih republika i pokrajina, Ustavni zakoni. 1974. Beograd: Prosveta.

Vince, Zlatko. 1959/60. Lalević, Naš pravopis. Beograd, 1958. Recenzija. Je$z i k, 2,60-61$.

Vukomanović, Slavko. 1987. Jezik, društvo, nacija. Beograd: Jugoslovenska revija.

Zaključci plenuma Društva književnika Hrvatske o problemima suvremenog jezika hrvatske književnosti, znanosti, školstva i sredstva masovne komunikacije; Rezolucija Zagrebačkog lingvističkog kruga; Izjava o jedinstvu i varijantama hrvatskosrpskog književnog jezika. 1966. Jezik, 5, 129-133. 


\section{О этноязыковой подитике в социалистической Югославии}

\section{Резюме}

В статье на примере хорватско-сербских этноязыковых отношений рассматриваются основные этапы развития хорватского дитературного языка в период образования и распада СФРЮ (1940- 1990 гг. ХХ в.).

Экстралингвистические попытки соединить хорватский и сербский языки в один сербохорватский/хорватосербский язык с помощью совместной стандартизации и унификации орфографий и лексики, отсутствие хорватского этнолингвонима и ограничение языковых прав на использование собственного языка вызвали волну протестов среди хорватской общественности. Результатом этноязыковых протестов явидось составление и опубликование в 1967 году “Декларации о названии и положении хорватского литературного языка" ("Deklaracija o nazivu i položaju hrvatskog književnog jezika“), которую подписали 18 научных, научно-педагогических учреждений и культурных обществ. Неудачи совместного языкового планирования связаны во многом с тем, что недостаточно полно учитывадись общие тенденции социальноэкономического, подитического и языкового развития, а также история межэтнических отношений двух народов, право на собственное развитие и наименование хорватского языка.

Внутригосударственная дезинтеграция, распад СФРЮ и образование на постюгославском пространстве новых государств не могли не сказаться на языковой ситуации, дивергентном развитии и функционировании языка хорватов, сербов, босняков и черногорцев. Поиски взаимоприемлемых решений по урегулированию этноязыковых разногласий, стандартизации и кодификации литературных языков названных этносов, посредством подписания Новисадского 1954 г. и Загребского 1986 г. соглашений, не привели стороны к общему языковому согласию. Аитературный хорватский и сербский языки в сложившейся социодингвистической ситуации в Хорватии, Сербии, Боснии и Герцеговины и Черногории прибрели собственный правовой статус и стали полностью развиваться самостоятельно.

Ključne riječi: etnojezična politika, srpskohrvatski/hrvatskosrpski jezik, hrvatski jezik, srpski jezik, unifikacija jezikâ, unitarizam

Ключевые слова: этноязыковая политика, сербохорватский / хорватосербский, хорватский язык, сербский язык, унификация языков, унитаризм 


\title{
Ethnolinguistic policy in socialist Yugoslavia
}

\begin{abstract}
In this article the main stages of Croatian literary language development in the period of formation and disintegration of Yugoslavia (1940. - 1990.) are considered on the example of Croatian-Serbian ethno-linguistic relations.

Extralinguistic attempts tojoin the Croatian and Serbian languages in SerboCroatian language through joint standardization and unification of orthographies and dictionary, the lack of Croatian ethnolinguonym and the restriction of linguistic rights to use their own language caused a wave of protests in Croatia. The result of ethno-linguistic protests was creation and publication of the Declaration on the name and status of Croatian literary language (Deklaracija o nazivu i položaju hrvatskog književnog jezika) in 1967, which was signed by 18 scientific-educational institutions and cultural societies. The failure of the joint language planning is largely associated with the fact that insufficient account is taken of the general trends in socioeconomic, political and language development, as well as the history of interethnic relations of the two peoples, the right for own development and name of the Croatian language.

Internal disintegration, the collapse of Yugoslavia and the formation on the postyugoslavian space of the new states affected the language situation, divergent development and functioning of the language of Croats, Serbs, Bosniaks and Montenegrins. The search for mutually acceptable solutions on the settlement of ethno-linguistic differences, standardization and codification of literary languages of the ethnic groups named by signing Novi Sad (1954) and Zagreb (1986) agreements had not led the parties to a common linguistic harmony. Literary Croatian and Serbian languages in the current sociolinguistic situation in Croatia, Serbia, Bosnia and Herzegovina and Montenegro acquired their own legal status and began to develop independently.
\end{abstract}

Ključne riječi: etnojezična politika, srpskohrvatski / hrvatskosrpski jezik, hrvatski jezik, srpski jezik, unifikacija jezikâ, unitarizam

Key words: ethnolinguistic politics, Serbo-Croatian / Croatian-Serbian, Croatian language, Serbian language, language unification, unitarianism 